\title{
INCREASING ESTRUS EXPRESSION IN LACTATING DAIRY COWS
}

by

JULIE A. SAULS

B.S., University of Missouri, 2014

\begin{abstract}
A THESIS
submitted in partial fulfillment of the requirements for the degree

MASTER OF SCIENCE

Department of Animal Sciences and Industry

College of Agriculture

KANSAS STATE UNIVERSITY

Manhattan, Kansas
\end{abstract}

2016

Approved by:

Major Professor

Dr. Jeffrey S. Stevenson 


\begin{abstract}
Using an activity monitoring system (AMS) equipped with an accelerometer, 2 experiments were conducted to test the hypotheses that: (1) altering progesterone before inducing luteolysis or (2) exposing cows to estradiol cypionate (ECP) or testosterone propionate (TP) after luteolysis would increase occurrence and intensity of estrus. In experiment 1 , cows $(n=154)$ were fitted with an AMS collar and a pressure-sensitive, rump-mounted device (HW) and assigned to 3 treatments: 1) $\mathrm{CL}$ only; 2) no $\mathrm{CL}+$ progesterone insert (CIDR); or 3) $\mathrm{CL}+2 \mathrm{CIDR}$ to achieve different concentrations of progesterone. Progesterone concentration 24 through $120 \mathrm{~h}$ post-treatment was greatest $(P<0.01)$ in $\mathrm{CL}+2 \mathrm{CIDR}$, followed by $\mathrm{CL}$, and no $\mathrm{CL}+\mathrm{CIDR}$ cows. Estrus occurred 11 to $12 \mathrm{~h}$ earlier $(P<0.01)$ in no $\mathrm{CL}+\mathrm{CIDR}$ compared with CL-bearing cows. Estrus intensity was greater $(P<0.05)$ after $\mathrm{CL}+2 \mathrm{CIDR}$ than $\mathrm{CL}$ only cows. The AMS and HW determined 68 and $62 \%$ of qualifying cows to be in estrus (estrus was defined: follicle $\geq$ $10 \mathrm{~mm}$ at $\mathrm{PGF}_{2 \alpha}$ and progesterone $\leq 0.5 \mathrm{ng} / \mathrm{mL} 72 \mathrm{~h}$ later), respectively. In experiment 2 , cows ( $n=203)$ were equipped with an AMS and a friction-activated, rump-mounted patch (Estrotect patch; ET) and assigned to receive $1 \mathrm{mg}$ ECP, $2 \mathrm{mg} \mathrm{TP}$, or control $24 \mathrm{~h}$ after $\mathrm{PGF}_{2 \alpha}$. Estradiol 24 h post treatment was greater $(P<0.01)$ in ECP compared with controls. Estrus expression detected by ET in all cows tended $(P=0.10)$ to be greater for ECP compared with controls. More $(P<0.05)$ qualifying cows were detected in estrus after ECP compared with controls. Compared with controls and in response to ECP, estrus occurred 17 to $20 \mathrm{~h}$ earlier $(P<0.01)$ and was of greater $(P<0.05)$ intensity. The AMS and ET determined 71 and $74 \%$ of cows to be in estrus, respectively. Of cows exposed to the AMS, HW, or ET, 62 to $74 \%$ were detected in estrus and more than $94 \%$ subsequently ovulated. In contrast, of the residual cows not detected in estrus, 60 to $76 \%$ ovulated in the absence of detected estrus. Only ECP was successful in inducing more
\end{abstract}


estrus expression and, proportions detected in estrus never exceeded $80 \%$. Given the large proportion of cows ovulating in the absence of estrus, further research is warranted to determine if conception is achievable by inseminating cows not detected in estrus by $80 \mathrm{~h}$ post-PGF ${ }_{2 \alpha}$.

Keywords: Estrus, estradiol, progesterone 


\section{Table of Contents}

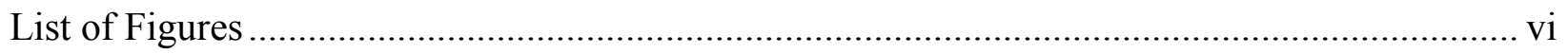

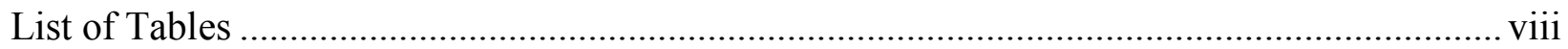

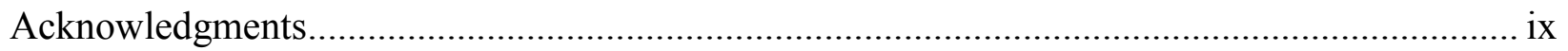

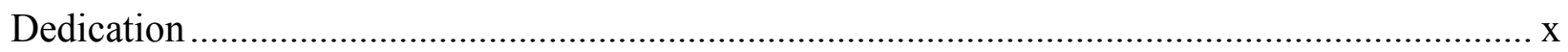

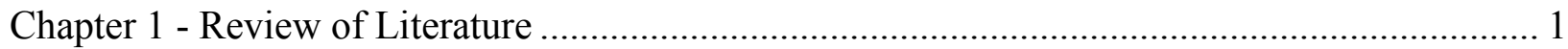

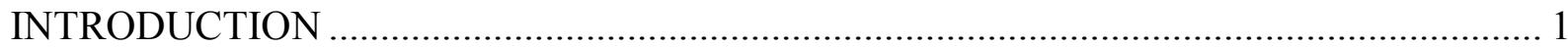

ROLE OF STEROID HORMONES ......................................................................... 1

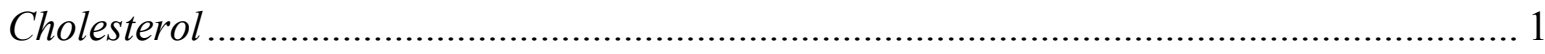

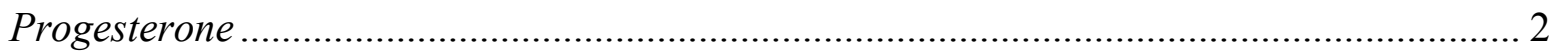

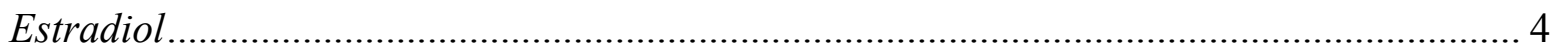

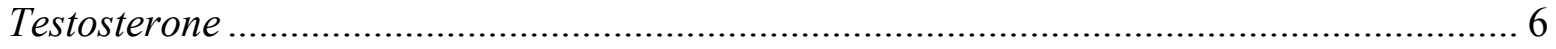

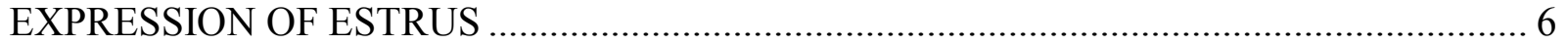

FACTORS INFLUENCING ESTRUS EXPRESSION ................................................... 7

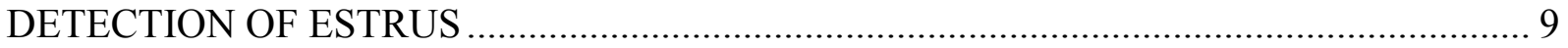

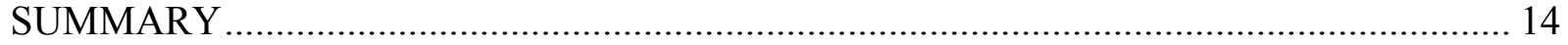

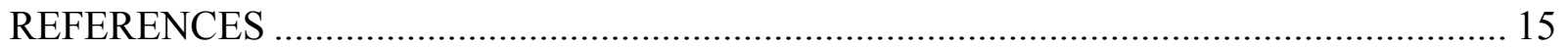

Chapter 2 - Increasing Estrus Expression in Dairy Cows .................................................... 24

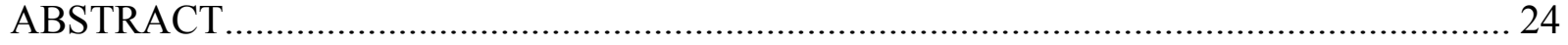

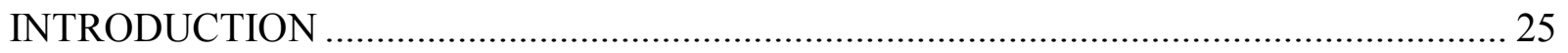

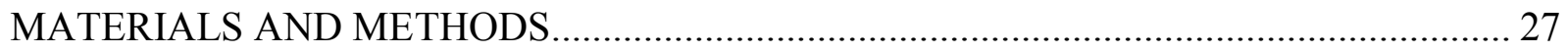

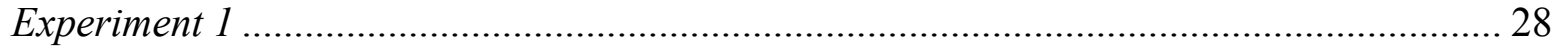

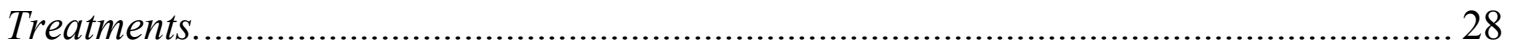

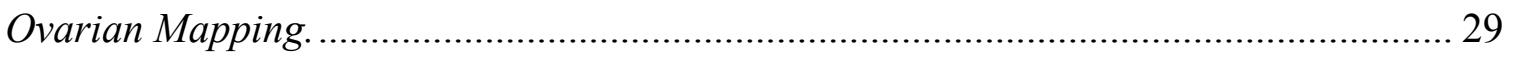

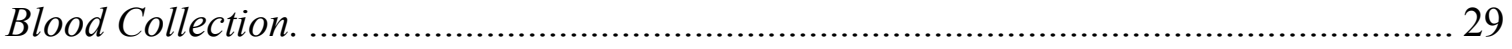

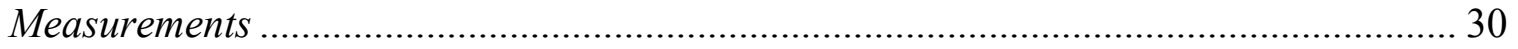

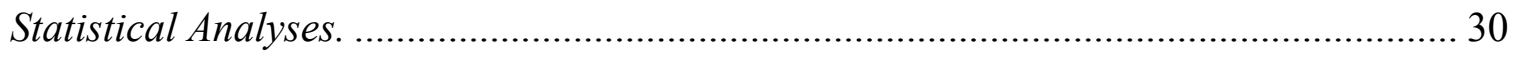

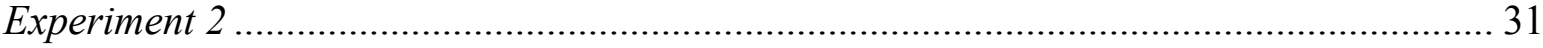

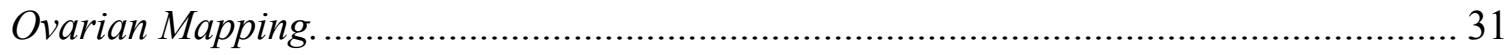

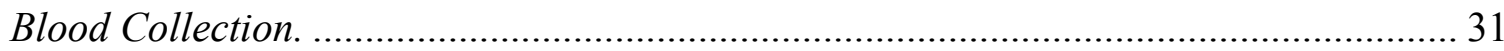




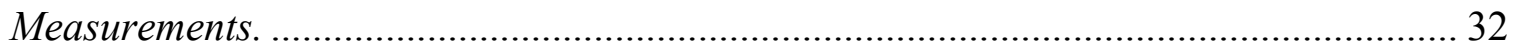

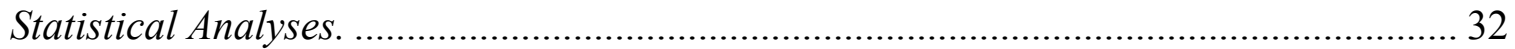

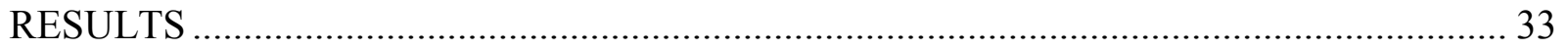

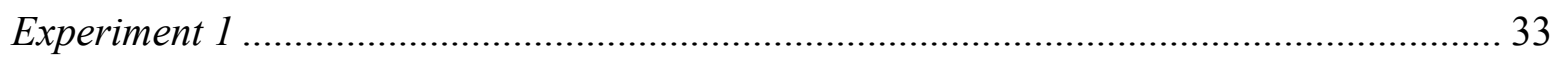

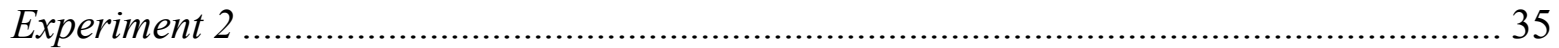

Efficiency and Accuracy of Detected Estrus ................................................................ 36

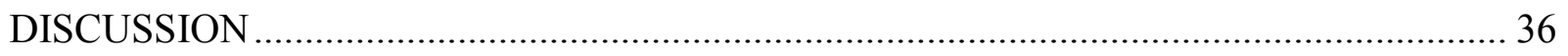

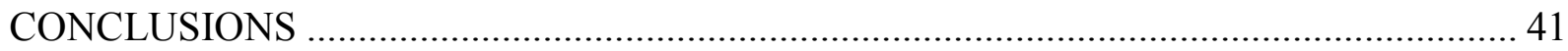

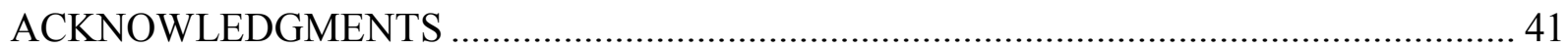

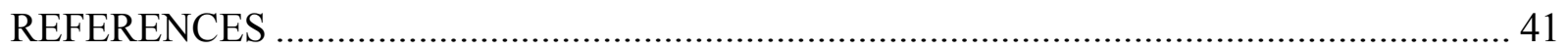




\section{List of Figures}

Figure 1. Experiment 1. On d-19, cows were treated with $\mathrm{PGF}_{2 \alpha}(\mathrm{PrePG} 1)$ and ovaries were scanned to determine follicle and CL location. On d -7 ovaries were scanned to determine the presence of a CL. Based on the CL status of cows on $d-7$, cows were preliminarily assigned randomly to treatment. Those cows assigned to the no CL + CIDR treatment received an injection of $\mathrm{PGF}_{2 \alpha}$ on $\mathrm{d}-7$ (PrePG2). Ovarian scans were performed on $\mathrm{d}-5$ to determine the presence of a CL, cows were assigned randomly to 3 treatments: (1) CL +2 CIDR (cows with a CL and 2 CIDR inserts); (2) CL only (cows with only $1 \mathrm{CL}$, control group); and (3) no CL + CIDR (cows without a CL and 1 CIDR insert). An automated monitoring system (AMS) and rump-mounted pressure sensitive device were fitted to each cow. On d 0 an injection of $\mathrm{PGF}_{2 \alpha}(\mathrm{PG})$ was administered to induce luteolysis, CIDR inserts were removed, and size of the dominant follicle was determined by ultrasound examination. Estrus activities were assessed during $7 \mathrm{~d}$ post $\mathrm{PGF}_{2 \alpha}$ injection via the AMS and pressure sensitive device. Blood samples were collected from a subset of cows $(n=101)$ on $d-5,-4$, $-2,0,1$, and, 2 , and from all cows $(\mathrm{n}=154)$ on $\mathrm{d} 0$ and 3 . Ovarian scans were performed on d 10 to determine ovulation. $\mathrm{CIDR}=$ progesterone-impregnated controlled internal drug release insert.

Figure 2. Experiment 2. Ovulation was synchronized with $\mathrm{GnRH}(\mathrm{d}-24), \mathrm{PGF}_{2 \alpha}(\mathrm{d}-17)$, and $\mathrm{GnRH}(\mathrm{d}-14)$ before cows were exposed to a progesterone insert and concurrent GnRH injection on $\mathrm{d}-7$. Inserts were removed, ovarian structures were mapped, and $\mathrm{PGF}_{2 \alpha}$ was administered on $\mathrm{d}$ 0. Cows received a second injection of $\mathrm{PGF}_{2 \alpha}$ on $\mathrm{d} 1$ and were assigned randomly to 3 treatments (TRT; d 1): $1 \mathrm{mg}$ ECP, $2 \mathrm{mg}$ TP, or a control with no injection. Blood samples $(\mathrm{BS})$ were collected from all cows $(\mathrm{n}=204)$ on d $0,1,2$, and 3. Ovarian scans were performed on d 10 to determine ovulation. $\mathrm{uCIDR}=$ once-used progesteroneimpregnated controlled internal drug release insert.

Figure 3. Mean $( \pm \mathrm{SE})$ concentrations of progesterone relative to injection of $\mathrm{PGF}_{2 \alpha}(\mathrm{d} 0)$ for all cows assigned to 3 treatments on $d-5$ (experiment 1): (1) CL only; (2) no CL + CIDR insert for $5 \mathrm{~d}$; or (3) $\mathrm{CL}+2 \mathrm{CIDR}=$ the presence of a CL and 2 CIDR inserts for $5 \mathrm{~d}$. On $\mathrm{d}$ 0, CIDR inserts were removed and all cows received $\mathrm{PGF}_{2 \alpha}$. Least squares means bearing different letters within day differ $(P<0.05)$. Error bars represent SEM. 
Figure 4. Mean $( \pm \mathrm{SE})$ concentrations of progesterone relative to injection of $\mathrm{PGF}_{2 \alpha}(\mathrm{d} 0)$ and 72 $\mathrm{h}$ later for all cows in 3 treatments on $\mathrm{d}-5$ (experiment 1): (1) CL only; (2) no CL + CIDR = $\mathrm{CL}+\mathrm{CIDR}$ insert for $5 \mathrm{~d}$; or (3) CL +2 CIDR inserts for $5 \mathrm{~d}$. On d 0 CIDR inserts were removed and all cows received $\mathrm{PGF}_{2 \alpha}$. Least squares means bearing different letters within day differ $(P<0.05)$. Error bars represent SEM. 51

Figure 5. Mean $( \pm \mathrm{SE})$ concentrations of progesterone relative to initial injection of $\mathrm{PGF}_{2 \alpha}(\mathrm{d} 0)$ for cows assigned to 3 treatments administered on d 1 (experiment 2): (1) $\mathrm{ECP}=1 \mathrm{mg}$ estradiol cypionate; (2) TP $=2 \mathrm{mg}$ testosterone propionate; or control $=$ no treatment injection. All cows received a second injection of $\mathrm{PGF}_{2 \alpha}$ on $\mathrm{d} 1$. Error bars represent SEM.

Figure 6. Mean $( \pm \mathrm{SE})$ concentrations of estradiol relative to initial $\mathrm{PGF}_{2 \alpha}$ injection $(\mathrm{d} 0)$ for cows assigned to 3 treatments administered on $\mathrm{d} 1$ (experiment 2): (1) ECP $=1 \mathrm{mg}$ i.m. estradiol cypionate; (2) $\mathrm{TP}=2 \mathrm{mg}$ i.m. testosterone propionate; (3) Control = no treatment injection; (d 1). All cows received a second injection of $\mathrm{PGF}_{2 \alpha}$ on $\mathrm{d} 1$. Least squares means bearing different letters within day differ $(P<0.05)$. Error bars represent SEM 53 


\section{List of Tables}

Table 1. Occurrence of estrus and ovulation in all cows fitted with an activity monitoring system (AMS) and a pressure sensitive device in experiment $1^{1}$ 54

Table 2. Occurrence of estrus and ovulation in qualifying cows fitted with an activity monitoring

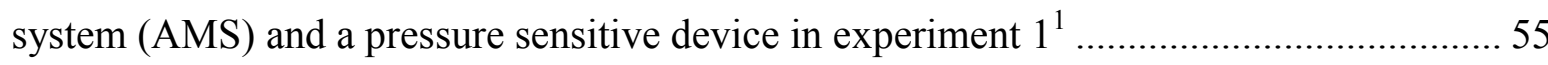

Table 3. Characteristics of estrus ( $\mathrm{LSM} \pm \mathrm{SEM}$ ) determined by automated activity monitoring system (AMS) or by a pressure sensitive device for qualifying cows in experiment $1^{1} \ldots \ldots . .56$

Table 4. Occurrence of estrus and ovulation in all cows fitted with an activity monitoring system (AMS) and a friction-activated patch in experiment $2^{1}$ 57

Table 5. Occurrence of estrus and ovulation in qualifying cows fitted with an activity monitoring

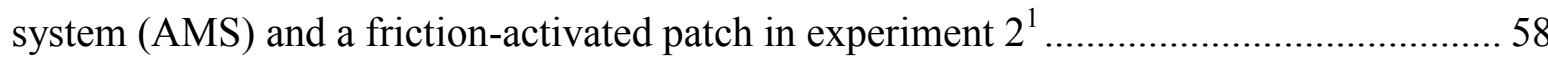

Table 6. Characteristics of estrus (LSM \pm SEM) determined by an activity monitoring system

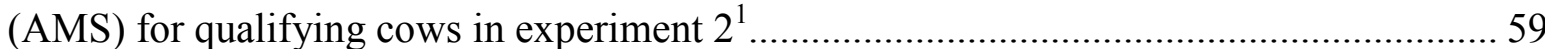

Table 7. Percentage of qualifying cows ${ }^{1}$ defined to be in estrus (efficiency), ovulated, or both (accuracy) detected by an activity monitoring system (AMS), pressure-sensitive devices, or friction-activated patches in experiments 1 and $2^{2}$ 60 


\section{Acknowledgments}

This research could not have successfully been completed without the contributions of many. I sincerely thank my fellow graduate students and the staff of Kansas State University who assisted with this project including, but not limited, to Michael Scheffel, Scott Hill, and Katie Olagaray. A special acknowledgment is made for Benjamin Voelz. He is a significant contributor to the work described here in and played a substantial role in assisting me with the transition to graduate school life. For your patience, advice, and friendship, thank you.

It is hard to put into words the affect my mentor, Dr. Stevenson, has had on my life. Through his intellect, character, and selfless nature I have been able to grow as a scientist and a person. I greatly appreciate all his time and effort invested in developing me as a student. For this, I sincerely say thank you.

"In every conceivable manner, the family is link to our past and the bridge to our future"Alex Haley. My family has been the definition of support as I pursed higher education. My parents have taught a work ethic that rivals the stigma of my generation as well as a sense of humility. For all of your life lessons and foundation of morals I am truly grateful. My siblings, extended family, and close friends have been filled with encouragement and support through this journey. I am appreciative of all your support. My support system would not be complete without the addition of Corey. For all of your love and encouragement, thank you. 


\section{Dedication}

The research summarized herein is dedicated to the pillars of my support system, Michael and Carole Sauls. Without their unconditional love and support I would not be the person I am today. 


\section{Chapter 1 - Review of Literature}

\section{INTRODUCTION}

Efficient dairy management practices are required to meet the demands of the world's growing population for dairy products. Reproductive efficiency is of major importance to the dairy industry (Yaniz et al., 2006). The average estrus-detection rate $(<50 \%)$ in most U.S. dairy herds has been identified as a major factor limiting reproductive efficiency (Lopez et al., 2005). Additional days open beyond the optimum time frame is costly for producers. Estrus expression is dependent on several variables including hormone concentrations, physiological, and environmental factors (Senger, 1994). In light of greater dependency on fixed-time artificial insemination programs, which exceed $85 \%$ of cows inseminated in large herds of 500 or more cows (Caraviello et al., 2006), new technologies have been developed to assist producers with estrus detection. Emerging technologies to detect secondary signs of estrus are undergoing validation trials to determine their accuracy to predict estrus. These new technology quantifies increased physical activity via pedometers or activity monitoring systems that incorporate accelerometers to monitor physical motion in 3 dimensions.

\section{ROLE OF STEROID HORMONES}

\section{Cholesterol}

Cholesterol is a 19-carbon planar structure with substituents found on carbons 17, 18, and 19. Sources of cholesterol for steroidogenesis are derived from several sources including: cellular membranes, cholesterol ester stores, circulating lipoproteins, or de novo cholesterol biosynthesis (Diaz et al., 2002). In ruminants, the main source of cholesterol for luteal cells is circulating high-density lipoproteins (Grummer and Carroll, 1988; Wiltbank et al., 1990). 
Cholesterol serves as the common precursor to all steroid hormone synthesis (Stocco, 2000). The rate limiting and hormonally regulated step in steroidogenesis is the delivery of cholesterol to the site of its first enzymatic conversion (1965; Karaboyas and Koritz, 1965; Brownie et al., 1972 Stocco, 2000).

Cholesterol is primarily a hydrophobic molecule which makes it difficult to freely diffuse across hydrophilic environments, thus, movement of cholesterol requires the utilization of transport proteins (Wiltbank et al., 2014). Cholesterol in the outer mitochondrial membrane, lipid droplets, or plasma membranes must be delivered to cytochrome P450 side-chain cleavage enzyme (P450scc) within the inner mitochondrial membrane. Steroidogenic acute regulatory (StAR) protein allows for cholesterol transfer to P450scc within the inner mitochondrial membrane (Stocco, 2000). The C-terminus of the StAR protein functions in cholesterol transport (Wang et al., 1998; Arakane et al., 1996; Stocco, 2000). The enzyme P450scc converts cholesterol to pregnenolone by an oxidative cleavage of cholesterol's side chain. Pregnenolone is the first steroid formed in all steroidogenic tissues (Stocco, 2000).

\section{Progesterone}

Discovery of progesterone began with the discovery of the corpus luteum (CL) by Regnier deGraaf (Jocelyn and Setchell, 1972). The CL was first referred to as "globules" by deGraaf and he concluded that the number of globules equaled the number of offspring resulting from a mating (Jocelyn and Setchell, 1972). Vilhelm Magnus and Ludwig Fraenkel performed bilateral ovariectomy or cautery with electrical heat in mated rabbits (Magnus and Simmer, 1972; Wiltbank, 2014). They concluded that the CL was essential for maintenance of pregnancy in rabbits (Wiltbank, 2014). Fraenkel continued these studies into the next decade and concluded that the CL regulates implantation and initial development of the embryo (Fraenkel, 1910). By 
1934, 4 laboratories independently isolated crystalline progesterone (Wiltbank, 2014). Willard M. Allen reported the structure of progesterone and is credited with the hormonal nomenclature.

Progesterone is a steroid hormone primarily secreted by the CL and the placenta of cattle (Wiltbank et al., 2014). Progesterone production from cholesterol utilizes two enzymes, CYP11A1 and HSD3 $\beta$. Progesterone production is considered the simplest steroidogenic pathway to produce a biologically active steroid (Wiltbank et al., 2014). Progesterone exits the cell and enters the blood stream where it is transported to target tissue (Hansel and Convey, 1983). The primary target tissues for progesterone in females are the hypothalamus, mammary glands, and uterus. Progesterone targets 2 components of the uterus: the glandular endometrium and the muscular myometrium. Progesterone not only stimulates maximal secretion from the endometrial glands that support development of the "free-floating" conceptus, but initiates lactation by causing final development of the alveolar cells in the mammary gland (Senger, 2012).

Circulating progesterone concentrations represent a balance between progesterone production and metabolism. Luteinizing hormones $(\mathrm{LH})$ is regulated by progesterone production from the CL. Circulating progesterone is greatest in ruminants at times of the cycle when LH pulse frequency is least (Wiltbank et al., 2012). Production of progesterone also is regulated by the number of granulosa cells that luteinize into large luteal cells. Progesterone production in luteal cells is related to transport of cholesterol within the cell (Wiltbank et al., 1993), whereas its metabolism is related to the amount of blood flow through the liver (Wiltbank et al., 2006).

Several implications exist for cows with low progesterone concentrations before artificial insemination (AI). The ovulatory follicular wave that develops in the absence of progesterone has increased risk for developing codominant follicles and double ovulation (Hayashi et al., 
2008). The risk of double ovulation decreases when progesterone concentrations are increased during the follicular growth phase (Stevenson et al., 2007a). Cows beginning an ovulationsynchronization program in a greater progesterone environment had increased pregnancy risk (43\%) compared with cows beginning the program with lesser progesterone concentrations (31.3\%; Bisinotto et al., 2010). Furthermore, cows ovulating a follicle from the second follicular wave of the estrous cycle during elevated progesterone concentrations had greater pregnancy per AI (P/AI) than cows ovulating a first follicular wave follicle (low progesterone; Bisinotto et al., 2010).

\section{Estradiol}

Discovery of estradiol began with the identification of estrone. Edgar Allen extracted fluids from sow's ovaries and injected it into immature rats and mice and observed the effect the fluid had on the uterus (Simpson and Santen, 2015). Doisy developed a multi-step purification process for refining estrone. In 1929, Doisy produced pure estrone crystals from pregnant women's urine. Alfred Butenandt, who purified estrone at the same time as Doisy, is credited with the purification of estrone. Doisy and colleagues later isolated a compound they called dihydrotheelin, which was later termed estradiol in 1940 (Simpson and Santen, 2015). In 1943, Edgar Allen and Edward Doisy postulated that the ovaries secrete a hormone (Simpson and Santen, 2015).

Estradiol is synthesized from androgens. According to the hypothesis of the 2-cell, 2gonadotropin model, theca interna cells of the follicle convert cholesterol to progesterone and then to androstenedione. Androstenedione is then transported across the basement membrane into the follicle cavity, where, under the influence of $17 \alpha$-hydroxylase and $\mathrm{P}_{450} 17_{\alpha}$, it is converted to estradiol-17 $\beta$ by the granulosa cells (Hansel and Convey, 1983). The primary target 
tissues for estradiol in the female are the hypothalamus, entire reproductive tract, and mammary glands.

In the relative absence of progesterone, estradiol's action in the hypothalamus induces estrus (Blache et al., 1991; Allrich, 1994). During proestrus of the bovine estrous cycle, a preovulatory follicle matures in either of the ovaries. Under the influence of follicle stimulating hormone (FSH) and LH, the preovulatory follicle secretes large amounts of estradiol that result in peak blood concentrations of estradiol (deSilva et al., 1981; Allrich 1994). Estradiol also is responsible for increased secretory activity of the reproductive tract and enhanced oviductal and uterine motility.

Once concentrations of estradiol are sufficient to induce estrus, additional amounts of estradiol have no further influence on the expression of estrus resulting in an "all or none" response (Allrich, 1994). The "all or none" response has been proven in both ovariectomized (Cook et al., 1987) and intact (Coe at al., 1989) females. Body weight is ignored when estrus is induced by estradiol injections because previous studies have demonstrated that an absolute dose of estradiol rather than a dosage based on BW successfully induced estrus (e.g., $0.5 \mathrm{mg}$ estradiol successfully induced estrus in cows ranging from 450 to $820 \mathrm{~kg}$ (Cook et al., 1986; Allrich, 1994).

High milk-producing dairy cows seem to lack sufficient blood concentrations of estradiol to induce estrus, ovulation, and uterine priming because of increased metabolic clearance of steroid hormones (Wiltbank et al., 2006). A greater proportion of cows receiving estradiol cypionate (ECP) expressed estrus (Sellars et al., 2006), or in lieu of GnRH (Stevenson et al., 2004), more were induced to ovulate compared with cows that did not receive ECP. It is believed the increased estrus expression occurred because of increased concentrations of estradiol (Sellars 
et al., 2006). Extending proestrus and supplementing cows with ECP increased occurrence of estrus generally $72 \mathrm{~h}$ after PGF2 $\alpha$ injections (Hillegrass et al., 2008).

\section{Testosterone}

Testosterone is a steroid hormone secreted by the theca interna cells of the ovarian follicle in females and from the Leydig cells of the testis (Hansel and Convey, 1983).

Testosterone and other androgens act as a substrate for the production of estradiol. Through the activity of $17 \beta$ hydroxyl-steroid dehydrogenase and cytochrome $\mathrm{P}_{450}$ aromatase, androstenedione is converted to testosterone, and then to estradiol-17 $\beta$. Testosterone's main target tissues in the female are the brain, skeletal muscle, and granulosa cells.

When testosterone propionate was administered without any other hormones, it was able to induce sexual behavior in ovariectomized cows (Kiser et al., 1977; Katz et al., 1980; Nessan et al., 1981; Allrich et al., 1989). In order to induce estrous behavior in cattle, large doses (100 to $400 \mathrm{mg}$ ) of testosterone are required; however, signs of estrus are not as obvious as when administering estradiol (Katz et al., 1980). Furthermore, testosterone does not inhibit the actions of estradiol when both are administered simultaneously (Fabre-Nys et al., 1993).

\section{EXPRESSION OF ESTRUS}

The estrous cycle is regulated by hormones from the hypothalamus, adenohypophysis, ovaries, and uterus via mechanisms of positive and negative feedback. The hypothalamus secretes gonadotropin-releasing hormone $(\mathrm{GnRH})$ from tonic and surge centers in the hypothalamus. Secreted GnRH then controls the secretion of the LH and FSH (Schally et al., 1971b). Pulses of GnRH are transported from the hypothalamus to the adenohypophysis via the hypophyseal portal veins (Moenter et al., 1992; Forde et al., 2011). Once in the adenohypophysis, GnRH binds to its G-protein coupled receptor on cell surfaces of gonadotroph 
cells (Kakar et al., 1993; Forde et al., 2011). The binding of GnRH to the G-protein receptor results in release of intracellular calcium to initiate release of FSH and LH (Weck et al., 1998). During the follicular phase of the estrous cycle, increased estradiol concentrations are secreted by the developing pre-ovulatory follicle (Forde et al., 2011). Greater concentrations of estradiol in conjunction with basal concentrations of progesterone that follow regression of the CL, triggers behavioral estrus and triggers a surge in GnRH (Forde et al., 2011). Estradiol is the primary signal to the brain that induces sexual behavior or estrus expression, but only in the absence of progesterone (Vailes et al., 1992; Forde et al., 2011).

\section{FACTORS INFLUENCING ESTRUS EXPRESSION}

Detection of behavioral estrus plays an important role in overall reproductive management programs in most U.S. dairies despite the widespread adoption of fixed time ovulation-synchronization programs (Caraviello et al., 2006; Fricke et al, 2014). Detecting estrus is fraught with many challenges, part of which are associated with how dairy cattle in the U.S. dairy industry are housed in confinement free stall barns with concrete surfaces. One of the most important factors affecting sexual activity in lactating Holstein cows is the surface on which they are observed for estrus (Britt et al., 1986). Cows are more likely to express estrus when housed on dirt surfaces rather than on dry-grooved concrete surfaces. When cows were observed in dirt lots during 30-min observation periods, they expressed longer periods of estrus and showed more total mounts and standing events than when observed in concrete lots (Britt et al., 1986). When an estrual cow is given the choice to mount on dirt or concrete, the cow prefers a dirt surface. Mounting activity is 15 -fold greater on dirt than on concrete (Vailes and Britt, 1990).

Average dairy herd size has increased during the past decade. With more cows per herd, and with more cows housed per pen, observation of individual cows is difficult at best. The 
number of cows simultaneously in estrus affects detection rates. The frequency at which heifers express primary signs of sexual receptivity increases simultaneously in proportion to the number of heifers in estrus (Helmer and Britt, 1985). Stage of the estrous cycle also affects detection rates because $86 \%$ of all attempted mounts in heifers were performed by heifers that were in the preestrual or estrual stages of the cycle (Helmer and Britt, 1985). To improve estrus-detection rates, therefore, it is recommended that females be induced artificially to express estrus in groups (Helmer and Britt, 1985).

Until recently, genetic selection for high milk yield has been the standard practice in AI sire selection (Egger-Danner et al., 2015). Because milk production affects expression of estrus, cows producing greater quantities of milk have shorter and less intense periods of estrus (Lopez et al., 2005). High-yielding cows have increased metabolic rates and to meet their nutritional requirements, dairy producers must feed diets containing more energy. As a result of these highenergy diets in lactating dairy cows, liver blood flow is chronically increased and metabolic clearance rate of estradiol and progesterone also is increased (Sangsritavong et al., 2002). Increased metabolic clearance of estradiol is counter-productive to expression of estrus because increased systemic concentrations of estradiol secreted by the preovulatory follicle are the triggering mechanism to initiate sexual behavior. Concentrations of estradiol were less for highproducing cows ( $\geq 39.1 \mathrm{~kg}$ per day) compared with low producing cows $24 \mathrm{~h}$ before estrus regardless of ovarian follicular diameter (Lopez et al., 2005). Therefore, high milk-producing cows are more prone to have difficulty expressing estrus because of decreased concentrations of estradiol. Furthermore, cows having greater daily milk production also have greater luteal tissue, but have reduced circulating concentrations of progesterone compared with lower producing cows (Lopez et al., 2005). 
Heat stress causes lactating cows to experience shorter duration and less intense estrus (Gwazdauskas et al., 1981; Younas et al., 1993). Long-term heat stress before day of breeding leads to reduced number of ovarian follicles, reduced concentration of estradiol in follicles, and an earlier emergence of the dominant follicle (Wolfenson et al., 1995; 1997).

During times of heat stress, cows showed reduced motor activity, mounting activity, and other manifestations of estrus (Hansen, 1997). Cows are at a greater risk for anestrus and silent ovulation during periods of heat stress (Gwazdauskas et al., 1981). Because the ovary is regulated by gonadotropins, heat-stressed cows have decreased LH pulse amplitude and LH pulse frequency (Gilad et al., 1993; Wise et al., 1988). As a result of decreased concentrations of LH during times of heat stress, the dominant follicle develops in a low LH environment (De Rensis and Scaramuzzi, 2003). A low LH environment yields reduced estradiol secretion from the dominant follicle resulting in poor estrus expression (De Rensis and Scaramuzzi, 2003). It has been suggested that increased concentrations of estradiol can counteract the negative effects of heat stress on estrus expression (De Rensis and Scaramuzzi, 2003).

\section{DETECTION OF ESTRUS}

Estrus detection plays an important role in overall reproductive management of dairy cattle in the United States (Senger, 1994). The cardinal sign of estrus, also termed behavioral estrus, is when a cow stands to be mounted by another herd mate or bull. Several secondary signs of estrus also exist that include changes in body temperature, blood flow, pheromones, hormones, milk yield, dry matter intake, vaginal cytology, $\mathrm{pH}$, electrical resistance of vaginal mucus, genital tissue, and physical activity (Lewis and Newman, 1984; Roelofs et al., 2010; Saint-Dizier and Chastant-Maillard, 2012). As dairies have moved to concrete confinementbased housing, estrus detection has suffered. In southeastern U.S. Holstein and Jersey herds, 
estrus-detection rates decreased from 50.9 and $59.6 \%$ in 1985 to 41.5 and $49.5 \%$ in 1999 , respectively (Washburn et al., 2002).

Methods for detecting estrus vary depending on the dairy operation. Before AI was adopted widely by the dairy industry, bulls were utilized to detect estrus and service cows in estrus. In dairy operations practicing natural service, little is known about breeding times, which in turn leads to a lack of breeding records. Given that one bull can service many cows, dairies using natural service to service their cow limit their rate for genetic gain for milk yield and other economic traits. Between 1984 and 1998, proven AI sired daughters produced 807 to 979 more pounds of milk than daughters of natural service bulls. In addition, bull breeding increases the potential for spreading venereal diseases throughout a herd (Foote, 1996). Because of benefits of using superior sires of known genetic backgrounds, most dairies adopted AI as their main method of breeding cows.

With increasing numbers of cows per milking herd and decreasing estrus-detection rates, new technologies have been developed to assist in estrus detection. The requirements of an "ideal" estrus-detection system include: (1) continuous surveillance of the cows; (2) accurate and automatic identification of the cow in estrus; (3) operation for the entire productive life of the cow; (4) minimize or eliminate labor required for estrus detection; and (5) high accuracy of identifying correct physiological and behavioral signs of estrus that correlate with ovulation (Senger, 1994).

Several low and high-tech products and systems have been developed to predict estrus. Detection of estrus can be accomplished by applying tail chalk, tail paint, and estrus-detection patches. Patches, paint, and chalk are used to determine a cow in estrus by patch activation (color change), or paint or chalk being rubbed off by a mounting cow. These techniques generally 
improve efficiency (more cows detected per unit of time), but not the accuracy of estrus detection. Paint and patches can be activated by means unrelated to estrus, thus leading to false positives.

When estrus detection is solely based on the primary sign of estrus (standing immobile for a few seconds to be mounted by a herd mate), observing cows for periods of $30 \mathrm{~min}, 2$ to 3 times daily, only detects 12 to $19 \%$ of animals in estrus (Firk et al., 2002). The HeatWatch system (HeatWatch 2; CowChips, Manalapan, NJ, USA) employs a pressure sensitive, rumpmounted device that contains a radio transmitter linked to a pressure sensor enclosed in a hard plastic case that are placed in nylon covers and glued to the rump of cows. The device is activated by the weight of a mounting herd mate, which triggers the radio transmission. The activity data are sent to a base station that receives the dataset and then downloads the data to a central computer in which a software algorithm analyzes the activity profile of each cow (SaintDizier and Chastant-Maillard, 2012). The efficiency of estrus detection for electronic heat-mount systems is usually more than $85 \%$ (Saint-Dizier and Chastant-Maillard, 2012). When compared with tail chalking method of estrus detection, significantly more standing events were detected by the HeatWatch system than by visual observations, but the system failed to result in a greater efficiency or accuracy of estrus detection (Palmer et. al., 2010). Complications occur when a heat-mount system is implemented on a commercial dairy farm. The rate of detected estrus may be less than desired because of the type of housing and the flooring to which the cows are exposed. Cows in estrus express more mounting activity in pasture or dry lots than in free-stall or tie-stall housing systems (De Silva et al., 1981; Palmer et al., 2010). Displacement of the pressure-sensitive device also can lead to missed mounts. Slope of dairy cow rump often causes the HeatWatch patch to be displaced sideways after a few mounts, thus preventing future 
recordings of activity. These systems can be falsely activated by pressure exerted when the device rubs against a bar in a tie-stall, free-stall bed, or stall separation bar (Palmer et al., 2010).

New technologies have been developed to measure secondary signs of estrus and other physical traits associated or correlated with estrus. Increase in physical activity is a commonly measured secondary sign of estrus. Cows spend considerably more time walking and less time resting and eating when in estrus (Kiddy, 1977). The average increase in activity at the time of estrus was 393\% (87 observations) when cows were housed in free-stall barns (Kiddy, 1977). Pedometers have been used to quantify steps taken by cows, and are a practical approach to assisting in estrus detection. Twenty-three of 108 cows in estrus (21\%) housed in free stalls were detected by pedometers, but missed by the herdsmen (Kiddy, 1977). Pedometers are attached to the leg of the cow just above the pastern and are read in the milking parlor or wirelessly in the barn. Some activity monitors, such as IceTag (IceRobotics Ltd., Edinburgh, UK), are removed from the cow and downloaded to a database (Silper et al., 2015). The main purpose of using the pedometer is to detect onset of estrus and to assist in the subsequent appropriate timing of AI (Roelofs et al., 2005b; Lovendahl et al., 2010).

Pedometers are limiting in several ways. In order for pedometers to be effective, day-today activity must be monitored (Kiddy, 1977). Data are usually only recorded 2 or 3 times daily depending on the farm milking schedule. Pedometers also can lead to false positives. The user also must establish a base line for each cow manually. With advancing technology, activity monitoring systems (AMS) are replacing the pedometers that do not employ accelerometers.

Accelerometers are small electromechanical devices that measure acceleration and are used in AMS. All AMS have 3 components: (1) the sensor(s) on each cow; (2) hardware receiver to collect the data from the sensors; and (3) computer software that outputs alerts and levels of 
activity (Nebel, 2015). Algorithms are used to analyze the data collected from AMS in the different ranges of motion including walking, eating, lying down, standing, head movement, etc. The collar-mounted Heatime accelerometer (Heatime; SCR Engineers Ltd., Netanya, Israel) uses a mathematical algorithm to express the momentary deviation of the activity from the average activity during the same time period during the most recent $7 \mathrm{~d}$ (Valenza et al., 2012). Using the Heattime accelerometer, approximately $70 \%$ of expected estrus activity was detected (Valenza et al., 2012). Many accelerometers store the cow's hourly activity and download the data to a transducer when entering the milking parlor or wirelessly via antenna placed in housing barns. This transducer stores and then relays the data to a personal computer. Dairies are not usually friendly environments for computers. With new advancements in technology, accelerometers can upload data to a cloud system and then be downloaded to any electronic device such as a smart phone, a personal computer, or tablet via internet connection. Because new AMS utilize the internet, this allows for global updating and on-screen graphics (Nebel, 2015). Accelerometer systems have increased reading of activity from twice daily to 12 or 24 times per day (Lovendahl et al., 2010). When an accelerometer system (Heattime) was compared with a pedometer system (IceTag), the 2 systems had greater precision of estrus detection and compatible measurements of estrus expression; however, the accelerometer was able to do so in real time, whereas the pedometer was not (Silper et al., 2015).

Several different types of accelerometers exist in the market: Heattime (SCR Engineers Ltd., Netanya, Israel), and DairyMaster MooMonitor (DairyMaster Co., Kerry, Ireland) are examples of neck-based accelerometers. CowManager (Agis Automatisering, Harmelen, Netherlands) is an example of ear tag based accelerometer. Some of these systems are advanced 
enough not only to detect movement, but also to monitor rumination, resting time, temperature, lying time, and other events associated with animal well-being (Nebel, 2015).

\section{SUMMARY}

In summary, 3 major steroid hormones (progesterone, testosterone, and estradiol) are involved in regulation of expression of sexual behavior. Estradiol, in the relative absence of progesterone, induces estrus. Estrus expression is dependent on many factors. The shift of the U.S. dairy industry from pasture- or dry lot-based housing to concrete confinement housing systems and greater herd size has led to less estrus expression and reduced intense observation of individual cows for signs of estrus. Because of genetic selection for greater milk yield, increased blood flow to the liver and increased metabolic clearance of estradiol, expression of estrus has likely been compromised. Environmental factors such as heat stress also deter estrus expression. Attempting to meet these challenges, new methods of detecting estrus other than twice daily observation of individual cows has been adopted by dairy farmers. These methods include electronic technologies to assess physical traits indicative of increased activity associated with estrus expression. The goal of these systems is to provide accurate accounts of animals' activity to assist in estrus detection. 


\section{REFERENCES}

Allrich, R. D. 1994. Estrus, new devices, and monitoring; endocrine and neural control of estrus in dairy cows. J. Dairy Sci. 77:2738-2744.

Allrich, R. D., D. L. Cook, L. A. Horstman, R. J. Knutson, and T. A. Winters. 1989. Influences of dexamethasone, progesterone, gonadotropin-releasing hormone, and testosterone on estrous behavior of estradiol-treated ovariectomized heifers. J. Dairy Sci. 72:2707-2711.

Arakane, F., T. Sugawara, H. Nishino, Z. Liu, H. A. Holt, D. Pain, D. M. Stocco, W. L. Miller, and J. F. Strauss III. 1996. Steroidogenic acute regulatory protein (StAR) retains activity in the absence of its mitochondrial import sequence: Implications for the mechanism of StAR action. Proc. Natl. Acad. Sci. USA 93:13731-13736.

Bisinotto R. S., R. C. Chebel, and J. E. Santos. 2010. Follicular wave of the ovulatory follicle and not cyclic status influences fertility of dairy cows. J. Dairy Sci. 93:3578-3587.

Blache, E. C., J. Fabre-Nys, and G. Venier. 1991. Ventromedial hypothalamus as a target for oestradiol action on proceptivity, receptivity, and luteinizing hormone surge of the ewe. Brain Res. 546:241-249.

Bownie, A. C., E. R. Simpson, C. R. Jefcoate, G. S. Boyd, W. H. Orme-Johnson, and H. Beinert. 1972. Effect of ACTH on cholesterol side-chain cleavage in rat adrenal mitochondria. Biochem. Biophys. Res. Commun. 46:483-490.

Britt, J. H., R. G. Scott, J. D. Armstrong, and M. D. Whitacre. 1986. Determinants of estrous behavior in lactating Holstein cows. J. Dairy Sci. 69:2195-2202.

Caraviello, D. Z., K. A. Weigel, P. M. Fricke, M. C. Wiltbank, M. J. Florent, N. B. Cook, K. V. Nordlund, N. R. Zwald, and C. L. Rawson. 2006. Survey of management practices on 
reproductive performance of dairy cattle on large US commercial farms. J. Dairy Sci. $89: 4723-35$.

Coe, B. L., and R. D. Allrich. 1989. Relationship between endogenous estradiol-17 $\beta$ and estrous behavior in heifers. J. Anim. Sci. 67:1546-1551.

Cook, D. L., T. A. Winters, L. A. Horstman, and R. D. Allrich. 1986. Induction of estrus in ovariectomized cows and heifers: effect of estradiol benzoate and gonadotropin-releasing hormone. J. Anim. Sci. 63:546-550

Cook, D. L., T. A. Winters, L. A. Horstman, and R. D. Allrich. 1987. Influence of cortisol and dexamethasone on estrous behavior of estradiol-treated ovariectomized cows and heifers. J. Dairy Sci. 70:181.

De Rensis, F., and R. J. Scaramuzzi. 2003. Heat stress and seasonal effects on reproduction in the dairy cow, a review. Theriogenology 60:1139-51.

De Silva, A. W. N. A., G. W. Anderson, F. C. Gwazdauskas, M. L. McGilliard, and J. A. Lineweaver. 1981. Interrelationships with estrous behavior and conception in dairy-cattle. J. Dairy Sci. 64:2409-2418.

Diaz, F. J., L. E. Anderson, Y. L. Wu, A. Rabot, S. J. Tsai, and M. C. Wiltbank. 2002. Regulation of progesterone and prostaglandin F-2 alpha production in the CL. Mol. Cell. Endocrinol. 191:65-80.

Egger-Danner C, J. B. Cole, J. E. Pryce, N. Gengler, B. Heringstad, A. Bradley, and K. F. Stock. 2015. Invited review: overview of new traits and phenotyping strategies in dairy cattle with a focus on functional traits. Animal 9:191-207. 
Favre-Nys, C., and G. B. Martin. 1993. Analysis of the hormonal control of female sexual behavior and the preovulatory LH surge in the ewe: roles of quantity of estradiol and duration of its presence. Horm. Behav. 27:108-121.

Firk, R., E. Stamer, W. Junge, and J. Krieter. 2002. Automation of oestrus detection in dairy cows: a review. Livest. Prod. Sci. 75:219-232.

Foote, R. H. 1996. Review: Dairy cattle reproductive physiology research and management-past progress and future prospects. J. Dairy. Sci. 79:980-990.

Forde, N., M. E. Beltman, P. Lonergan, M. Diskin, J. F. Roche, and M. A. Crowe. 2011. Oestrous cycle in bos Taurus cattle. Anim. Reprod. Sci. 124:163-169.

Fraenkel, L. 1910. Neue experiment zur function des corpus luteum. Archi. Gynakologie 91:705-730.

Fricke, P. M., P. D. Carvalho, J. O. Giordano, A. Valenza, G. Lopes Jr., and M. C. Amundson. 2014. Expression and detection of estrus in dairy cows: the role of new technologies. Animal 8:134-143.

Gilad, E., R. Meidan, A. Berman, Y. Graber, and D. Wolfenson. 1993. Effect of heat stress on tonic and GnRH-induced gonadotrophin secretion in relation to concentration of oestradiol in plasma of cyclic cows. J. Reprod. Fertil. 99:315-21.

Grummer, R. R., and D. J. Carroll. 1988. A review of lipoprotein cholesterol metabolism: importance to ovarian function. J. Anim. Sci. 66:3160-3173.

Gwazdauskas, F. C., W. W. Thatcher, C. A. Kiddy, M. J. Pape, and C. J. Wilcox. 1981. Hormonal pattern during heat stress following $\mathrm{PGF}_{2 \alpha^{-}}$tham salt induced luteal regression in heifers. Theriogenology 16:271-85.

Hansel, W., and E. M. Convey. 1983. Physiology of the estrous cycle. J. Anim. Sci. 57:404-424. 
Hayashi, K. G., M. Matsui, T. Shimitzu, N. Sudo, A. Sato, K. Shirasuna, M. Tetsuka, K. Kida, D. Schams, and A. Miyamoto. 2008. The absence of corpus luteum formation alters the endocrine profile and affects follicular development during the first follicular wave in cattle. Reproduction 136:787-797.

Hansen, P. J. 1997. Strategies for enhancing reproduction of lactating dairy cows exposed to heat stress. Proc. $16^{\text {th }}$ Con. Amer. Embryo Trans. Assoc. Madison. Pp. 62-72.

Helmer, S. D., and J. H. Britt. 1985. Mounting behavior as affected by stage of estrous cycle in Holstein heifers. J. Dairy Sci. 68:1290-96.

Hillegrass, J., F. S. Lima, M. F. Sa Filho, and J. E. P. Santos. 2008. Effect of time of artificial insemination and supplemental estradiol on reproduction of lactating dairy cows. J. Dairy Sci. 91:4226-4237.

Jocelyn, H. D., and B. P. Setchell. 1972. An annotated translation of Regnier deGraaf's new treatise concerning the generative organs of women (1672). J. Reprod. Fertil. 17:77-206.

Kakar, S. S., C. H. Rahe, and J. D. Neil. 1993. Molecular cloning, sequencing, and characterizing the bovine receptor for gonadotropin-releasing hormone (GnRH). Domest. Anim. Endocrinol. 10:335-342.

Karaboyas, G. C, and S. B. Koritz. 1965. Identity of the site of action of cAMP and ACTH in corticosteroidogenesis in rat adrenal and beef adrenal cortex slices. Biochemistry 4:462-468.

Katz, L. S., E. A. B. Oltenacu, and R. H. Foote. 1980. The behavioral responses in ovariectomized cattle to either estradiol, testosterone, androstenedione, or dihydrotestosterone. Horm. Behav. 14:224.

Kiddy, C. A. 1977. Variation in physical activity as an indication of estrus in dairy cows. J. Dairy Sci. 60:235-243. 
Kiser, T. E., J. H. Britt, and H. D. Ritchie. 1977. Testosterone treatment of cows for use in detection of estrus. J. Anim. Sci. 44:1030-1035.

Lewis, G. S., and S. K. Newman. 1984. Changes throughout estrous cycles of variables that might indicate estrus in dairy cows. J. Dairy Sci. 67:146-152.

Lopez, H., D. Z. Caraviello, L. D. Satter, P. M. Fricke, and M. C. Wiltbank. 2005. Relationship between level of milk production and multiple ovulations in lactating dairy cows. J. Dairy Sci. 88:2783-93.

Lovendahl, P., and M. G. G. Chagunda. 2010. On the use of physical activity monitoring for estrus detection in dairy cows. J. Dairy Sci. 93:249-259.

Magnus V., and H. H. Simmer. 1972. The first experiments to demonstrate an endocrine function of the corpus luteum. II. Ludwig Fraenkel versus Vilhelm magnus. Sudhoffs Arch. 56:76-99.

Moenter, S. M., R. C. Brand, and F. J. Karsch. 1992. Dynamics of gonadotropin-releasing hormone $(\mathrm{GnRH})$ secretion during the GnRH surge: insights into the mechanism of GnRH surge induction. Endocrinology 130:2978-2984.

Nebel, R. 2015. Activity monitoring systems: what's new and what's improved? In Dairy Cattle Reprod. Council Proc., Buffalo, NY, pp 1-7.

Nessan, G. K., and G. J. King. 1981. Sexual behavior in ovariectomized cows treated with oestradiol benzoate and testosterone propionate. J. Reprod. Fertil. 61:171.

Palmer, M. A., G. Olmos, L. A. Boyle, and J. F. Mee. 2010. Estrus detection and estrus characteristics in housed and pastured Holstein-Friesian cows. Theriogenology 74:255-264.

Rensis, F. D., and R. J. Scaramuzzi. 2003. Heat stress and seasonal effects on reproduction in the dairy cow- a review. Theriogenology 60:1139-1151. 
Roelofs, J. F., Lopez-Gatius, R. H. F. Hunter, F. J. C. M. van Eerdenburg, and Ch. Hanzen. 2010. When is a cow in estrus? Clinical and practical aspects. Theriogenology 74:327-344.

Roelofs, J. B., F. J. C. M. van Eerdenburg, N. M. Soede, and B. Kemp. 2005. Various behavioral signs of estrous and their relationship with time of ovulation in dairy cattle. Theriogenology 63:1366-1377.

Saint-Dizier, M., and S. Chastant-Maillard. 2012. Towards an automated detection of oestrus in dairy cattle. Reprod. Domest. Anim. 47:1056-1061.

Sangsritavong, S., D. K. Combs, R. Sartori, L. E. Armentano, and M. C. Wiltbank. 2002. High feed intake increases liver blood flow and metabolism of progesterone and estradiol-17 $\beta$ in dairy cattle. J. Dairy Sci. 85:2831-42.

Schally, A. V., A. Arimura, A. J. Kastin, H. Matsuo, Y. Baba, T. W. Redding, R. M. Nair, L. Debeljuk, and W. F. White. 1971b. Gonadotropin-releasing hormone: one polypeptide regulates secretion of luteinizing and follicle stimulating hormones. Science 173:1036-1038.

Sellars, C. B., J. C. Dalton, R. Manzo, J. Day, and A. Ahmadzadeh. 2006. Time and incidence of ovulation and conception rates after incorporating estradiol cypionate into a timed artificial insemination protocol. J. Dairy Sci. 89:620-626.

Senger, P. L. 1994. The estrus detection problem: new concepts, technologies, and possibilities. J. Dairy Sci. 77:2745-53.

Senger, P. L. 2012. Pathways to pregnancy and parturition. 3rd edition. Current Conceptions, Inc. Redmond, OR.

Silper, B. F., A. M. L. Madureira, M. Kaur, T. A. Burnett, and R. L. A. Cerri. 2015. Short communication: comparison of estrus characteristics in Holstein heifers by 2 activity monitoring systems. J. Dairy Sci. 98:3158-65. 
Simpson, E., and R. J. Santen. 2015. Celebrating 75 years of oestradiol. J. Mol. Endocrinol. 55:T1-20. doi: 10.1530/JME-15-0128. Epub 2015 Oct 5.

Stevenson, J. S., M. A. Portaluppi, and D. E. Tenhouse. 2007. Factors influencing upfront singleand multiple-ovulation incidence, progesterone, and luteolysis before a timed insemination resynchronization protocol. J. Dairy Sci. 90:5542-5551.

Stevenson, J. S., S. M. Tiffany, and M. C. Lucy. 2004. Use of estradiol cypionate as a substitute for GnRH in protocols for synchronizing ovulation in dairy cattle. J. Dairy Sci. 87:32893305.

Stocco, D. M. 2000. The role of the StAR protein in steroidogenesis: challenges for the future. Endocrinology 164:247-253.

Vailes, L. D., and J. H. Britt. 1990. Influence of footing surface on mounting and other sexual behaviors of estrual Holstein cows. J. Anim. Sci. 68:2333-39.

Vailes, L. D., S. P. Washburn, and J. H. Britt. 1992. Effects of various steroids milieus or physiological states on sexual behavior of Holstein cows. J. Anim. Sci. 70:2094-2103.

Valenza, A., J. O. Giordano, G. Lopes Jr., L. Vincenti, M. C. Amundson, and P. M. Fricke. 2012. Assessment of an accelerometer system for detection of estrus and treatment with gonadotropin-releasing hormone at the time of insemination in lactating dairy cows. J. Dairy Sci. 95:7115-27.

Wang, X. J., Z. Liu, S. Eimerl, A. M. Weiss, J. Orly, and D. M. Stocco. 1998. Effect of truncated forms of the steroidogenic acute regulatory (StAR) protein on intramitochondrial cholesterol transfer. Endocrinology 139:3903-3912. 
Washburn, S. P., W. J. Silvia, C. H. Brown, B. T. McDaniel, and A. J. McAllister. 2002. Trends in reproductive performance in southeastern Holstein and jersey DHI herds. J. Dairy Sci. $85: 244-251$.

Weck, J., P. C. Fallest, L. K. Pitt, and M. A. Shupnik. 1998. Differential gonadotropin-releasing hormone stimulation of rat luteinizing hormone subunit gene transcription by calcium influx and mitogen-activated protein kinase-signaling pathways. J. of Mol. Endocrinol. 12:451-457.

Wiltbank M. C., C. J. Belfiore, and G. D. Niswender. 1993. Steroidogenic enzyme activity after acute activation of protein-kinase (PK) A and PKC in ovine small and large luteal cells. J. Mol. Cell. Endocrinol. 97:1-7.

Wiltbank, M. C., M. G. Diskin, J. A. Flores, and G. D. Niswender. 1990. Regulation of the corpus luteum by protein kinase $\mathrm{C} 2$. Inhibition of lipoprotein-stimulated steroidogenesis by prostaglandin-f2-alpha. Biol. Reprod. 42:239-245.

Wiltbank, M. C., H. Lopez, R. Sartori, S. Sangsritavong, and A. Gumen. 2006. Changes in reproductive physiology of lactating dairy cows due to elevated steroid metabolism. Theriogenology 65:17-29.

Wiltbank, M. C., S. M. Salih, M. O. Atli, W. Luo, C. L. Bormann, J. S. Ottobre, C. M. Vezina, V. Mehta, F. J. Diaz, S. J. Tsai, and R. Sartori. 2012. Comparison of endocrine and cellular mechanisms regulating the corpus luteum of primates and ruminants. Anim. Reprod. Sci. 9:242-259.

Wiltbank, M. C., A. H. Souza, P. D. Carvalho, A. P. Cunha, J. O. Giordano, P .M. Fricke, G. M. Baez, and M. G. Diskin. 2014. Physiological and practical effects of progesterone on reproduction in dairy cattle. Animal 8:70-91. 
Wise, M. E., D. V. Armstrong, J. T. Huber, R. Hunter, and F. Wiersma. 1988. Hormonal alterations in the lactating dairy cow in response to thermal stress. J. Dairy Sci. 71:24802485.

Wolfenson, D., W. W. Thatcher, L. Badinga, J. D. Savio, R. Meidan, B. J. Lew, R. Braw-Tal, and A. Berman. 1995. Effect of heat stress on follicular development during the estrous cycle in lactating dairy cattle. Biol. Reprod. 52:1106-1113

Wolfenson, D., B. J. Lew, W. W. Thatcher, Y. Graber, and R. Meidan. 1997. Seasonal and acute heat stress effects on steroid production by dominant follicles in cows. Anim. Reprod. Sci. 47:9-19.

Yaniz, J. L., P. Santolaria, A. Giribet, and F. Lopez-Gatius. 2006. Factors affecting walking activity at estrus during postpartum period and subsequent fertility in dairy cows. Theriogenology 66:1943-1950.

Younas, M., J. W. Fuquay, A. E. Smith, and A. B. Moore. 1993. Estrus and endocrine responses of lactating Holsteins to forced ventilation during summer. J. Dairy Sci. 76:430-4. 


\title{
Chapter 2 - Increasing Estrus Expression in Dairy Cows
}

\author{
ABSTRACT \\ Using an activity monitoring system (AMS) equipped with an accelerometer, 2 \\ experiments were conducted to test the hypotheses that: (1) altering progesterone before inducing \\ luteolysis or (2) exposing cows to estradiol cypionate (ECP) or testosterone propionate (TP) after \\ luteolysis would increase occurrence and intensity of estrus. In experiment 1 , cows $(n=154)$ \\ were fitted with an AMS collar and a pressure-sensitive, rump-mounted device (HW) and \\ assigned to 3 treatments: 1) CL only; 2) no $\mathrm{CL}+$ progesterone insert (CIDR); or 3) $\mathrm{CL}+2 \mathrm{CIDR}$ \\ to achieve different concentrations of progesterone. Progesterone concentration 24 through $120 \mathrm{~h}$ \\ post-treatment was greatest $(P<0.01)$ in $\mathrm{CL}+2 \mathrm{CIDR}$, followed by $\mathrm{CL}$, and no $\mathrm{CL}+\mathrm{CIDR}$ \\ cows. Estrus occurred 11 to $12 \mathrm{~h}$ earlier $(P<0.01)$ in no $\mathrm{CL}+\mathrm{CIDR}$ compared with CL-bearing \\ cows. Estrus intensity was greater $(P<0.05)$ after $\mathrm{CL}+2 \mathrm{CIDR}$ than $\mathrm{CL}$ only cows. The AMS \\ and HW determined 68 and $62 \%$ of qualifying cows to be in estrus (estrus was defined: follicle $\geq$ \\ $10 \mathrm{~mm}$ at $\mathrm{PGF}_{2 \alpha}$ and progesterone $\leq 0.5 \mathrm{ng} / \mathrm{mL} 72 \mathrm{~h}$ later), respectively. In experiment 2 , cows \\ ( $n=203$ ) were equipped with an AMS and a friction-activated, rump-mounted patch (Estrotect \\ patch; ET) and assigned to receive $1 \mathrm{mg}$ ECP, $2 \mathrm{mg} \mathrm{TP}$, or control $24 \mathrm{~h}$ after $\mathrm{PGF}_{2 \alpha}$. Estradiol 24 \\ h post treatment was greater $(P<0.01)$ in ECP compared with controls. Estrus expression \\ detected by ET in all cows tended $(P=0.10)$ to be greater for ECP compared with controls. More \\ $(P<0.05)$ qualifying cows were detected in estrus after ECP compared with controls. Compared \\ with controls and in response to ECP, estrus occurred 17 to $20 \mathrm{~h}$ earlier $(P<0.01)$ and was of \\ greater $(P<0.05)$ intensity. The AMS and ET determined 71 and $74 \%$ of cows to be in estrus, \\ respectively. Of cows exposed to the AMS, HW, or ET, 62 to $74 \%$ were detected in estrus and \\ more than $94 \%$ subsequently ovulated. In contrast, of the residual cows not detected in estrus, 60
}


to $76 \%$ ovulated in the absence of detected estrus. Only ECP was successful in inducing more estrus expression and, proportions detected in estrus never exceeded $80 \%$. Given the large proportion of cows ovulating in the absence of estrus, further research is warranted to determine if conception is achievable by inseminating cows not detected in estrus by $80 \mathrm{~h}$ post- $\mathrm{PGF}_{2 \alpha}$. Keywords: Estrus, estradiol, progesterone

\section{INTRODUCTION}

Reproductive efficiency is of major importance to the dairy industry (Yaniz et al., 2006). Average estrus-detection risk $(<50 \%)$ in most U.S. dairy herds have been identified as a major factor limiting reproductive efficiency (Lopez et al., 2005). Less than optimal days open are costly to producers. Detection of behavioral estrus plays an important role in overall reproductive management programs in most U.S. dairies despite the widespread adoption of fixed time ovulation-synchronization programs (Caraviello et al., 2006; Fricke et al., 2014). Furthermore, other physiological changes are associated with primary and secondary signs of estrus including: vaginal cytology, $\mathrm{pH}$, electrical resistance of vaginal mucus, genital tissue, physical activity, changes in body temperature, blood flow, pheromones, hormones, milk yield, and DM intake, (Lewis and Newman, 1984; Roelofs et al., 2010; Saint-Dizier and Chastant-Maillard, 2012). In summary, expression of behavioral estrus is dependent on several factors including hormone concentrations, physiological, and environmental factors (Senger, 1994).

A large proportion of the large herds in the U.S. dairy industry houses dairy cows in confinement free stall barns with concrete flooring. One of the most important factors limiting expression of sexual behavior in lactating Holstein cows is the surface on which they are observed for estrus (Britt et al., 1986). Cows are more likely to express estrus when housed on dirt surfaces rather than on dry grooved concrete surfaces. Because milk production affects estrus 
expression, and until recently, genetic selection for only increased milk yield has been the standard practice in AI sire selection (Egger-Danner et al., 2015), cows producing greater quantities of milk have shorter and less intense periods of estrus (Lopez et al., 2005). In addition, high-yielding cows have increased metabolic rates, and to meet their nutritional requirements, dairy producers must feed diets with more concentrated energy. As a result of these high-energy diets in lactating dairy cows, liver blood flow is chronically increased and metabolic clearance rate of estradiol and progesterone also is increased (Sangsritavong et al., 2002), thus reducing systemic concentrations of these 2 steroid hormones.

Cows beginning an ovulation-synchronization program with greater progesterone concentrations had more pregnancies per AI (P/AI) compared with cows beginning the program with lesser progesterone concentrations (Bisinotto et al., 2010). Furthermore, cows ovulating a follicle from the second follicular wave of the estrous cycle during elevated concentrations of progesterone had greater P/AI than cows ovulating a first follicular wave follicle (low progesterone; Bisinotto et al., 2010). High milk-producing dairy cows seem to lack sufficient blood concentrations of estradiol to induce estrus, ovulation, and uterine priming because of increased metabolic clearance of steroid hormones (Wiltbank et al., 2006). A greater proportion of cows expressed estrus that received estradiol cypionate (ECP; Sellars et al., 2006), in lieu of GnRH (Stevenson et al., 2004), to induce ovulation compared with cows that did not receive ECP. Increased estrus expression resulted from greater concentrations of estradiol (Sellars et al., 2006). When testosterone propionate was administered without any other hormones, it was able to induce sexual behavior in ovariectomized cows (Kiser et al., 1977). In order to induce estrus in cattle, large doses (100 to $400 \mathrm{mg}$ ) of testosterone are required; however, signs of estrus were not as obvious as after administering estradiol (Katz et al., 1980). Furthermore, testosterone does 
not inhibit the actions of estradiol when both are administered simultaneously (Fabre-Nys et al., 1993).

New technologies are available to assist in detecting various physiological traits that are correlated with estrus. Increased physical activity is a commonly measured correlate of estrus. Cows spend considerably more time walking and less time resting and eating when in estrus (Kiddy, 1977). The average increase in activity at the time of estrus was $393 \%$ when cows were housed in free stall barns as assessed by pedometry (Kiddy, 1977). With the advancement of technology, pedometers are being replaced with more sophisticated activity monitoring systems (AMS) to help dairy producers identify increased activity associated with estrus. Activity monitoring systems have increased reading of activity from twice daily (as with pedometers) to 12 or 24 times per day (Lovendahl et al., 2010). When an AMS (i.e., Heattime) was compared with a pedometer system (i.e., IceTag), the 2 systems had greater precision of estrus detection when compared with visual observation and compatible measurements of estrus expression. Many AMS measure changes in activity in real time (Silper et al., 2015).

Using a market-available automated AMS, our objectives were to test the hypotheses that: (1) altering progesterone before inducing luteolysis or (2) exposing cows to estradiol cypionate (ECP) or testosterone propionate (TP) after luteolysis would increase occurrence and intensity of estrus.

\section{MATERIALS AND METHODS}

Two experiments conducted at the Kansas State University Dairy Research and Teaching Center were approved by the Kansas State University Institutional Animal Care and Use Committee (Manhattan). Lactating Holstein cows were housed at the Kansas State University Dairy Teaching and Research Center in covered free stalls and fed twice or thrice daily a TMR 
calculated to meet nutritional requirements for lactating dairy cows producing $50 \mathrm{~kg}$ of $3.5 \%$ milk (NRC, 2001). The diet consisted of alfalfa hay, corn silage, soybean meal, whole cotton seed, corn or milo grain, corn-gluten feed, vitamins, and minerals. Cows were milked thrice daily.

\section{Experiment 1}

Treatments. This experiment was conducted to determine if intensity and occurrence of estrus was altered by exposing cows to increasing concentrations of progesterone before treatment with $\mathrm{PGF}_{2 \alpha}$. To determine expression and intensity of estrus (identified by the activity software), cows were enrolled in a study beginning at $53 \pm 3$ DIM (Figure 1). Cows were administered 25 mg PGF $2 \alpha$ (Lutalyse, Zoetis Animal Health, Florham Park, NJ) 19 d before final luteolysis induction (d 0). Every third cow was administered an additional injection of $\mathrm{PGF}_{2 \alpha} 7 \mathrm{~d}$ before luteolysis induction. Using transrectal ovarian ultrasonography (7.5-MHz linear-array transducer, Aloka 500V; Corometrics Medical System Inc., Wallingford, CT), presence of a corpus luteum (CL) was determined $5 \mathrm{~d}$ before administering $25 \mathrm{mg} \mathrm{PGF} 2 \alpha(\mathrm{d} 0)$; to induce luteolysis. Based on the absence or presence of a CL on $d-5,155$ cows were assigned to 3 treatments: (1) cows $(\mathrm{n}=52)$ without a CL were administered a progesterone-impregnated (1.39 $\mathrm{ng} / \mathrm{mL}$ ) controlled internal drug release insert(CIDR; Zoetis Animal Health; no CL + CIDR); (2) cows $(n=51)$ with a CL were treated with 2 CIDR inserts (CL +2 CIDR); or ( 3$)$ cows $(n=51)$ with a CL served as controls (CL only). Cows were fitted with neck-collar-mounted AMS (Dairymaster [DM] MooMonitors, Dairymaster Inc., Kerney, Ireland). In addition, each cow also was fitted with a rump-mounted, pressure sensitive device (HeatWatch [HW], Cow Chips LLC, Manalapan, NJ). The AMS use a microelectronic motion-sensing accelerometer that measured 3dimensional movement in $\mathrm{m}_{\text {per }} \mathrm{s}^{2}$ (quantified as counts in the software). One of the AMS 
algorithms calculated standard deviation increase of motion during 3 previous hours of activity (quantified as factors in the software). Monitors uploaded information to a base station located in the holding pen when cows came to the parlor to be milked thrice daily. Body condition scores (0.25-point increments; $1=$ thin and $5=$ fat; Ferguson et al., 1994) of cows were assessed on $\mathrm{d}$ -5. On d 0, CIDR inserts were removed and cows were administered i.m. 25 mg PGF Pa $_{2 \alpha}$ (Lutalyse; Zoetis Animal Health). Cows were monitored for estrus during $7 \mathrm{~d}$ after $\mathrm{PGF}_{2 \alpha}$ and cows were inseminated after estrus was detected ( 8 to $12 \mathrm{~h}$ after activity threshold or after onset of first standing event).

To determine the true value (efficiency and accuracy) of the estrus-detection devices in detecting estrus, estrus was defined to have occurred when at least 1 ovarian follicle $\geq 10 \mathrm{~mm}$ was identified on $\mathrm{d} 0$ and progesterone was $\leq 0.5 \mathrm{ng} / \mathrm{mL}$ on $\mathrm{d} 3$. These cows were categorized as qualifying cows (i.e., those that should be in true physiological estrus and should demonstrated sexual behavior including standing estrus). Efficiency was assessed by the proportions of qualifying cows of total enrolled cows that were detected in estrus by the device. Accuracy was assessed by the proportion of cows detected in estrus that subsequently ovulated.

Ovarian Mapping. Transrectal ovarian ultrasonography (7.5-MHz linear-array transducer, Aloka 500V; Corometrics Medical Systems Inc., Wallingford, CT) was performed on $\mathrm{d}-5$ to measure and map location of follicle diameters and location of each CL. Scans were repeated on $\mathrm{d} 0$ to determine dominant follicle diameter and on $\mathrm{d} 10$ to determine ovulation.

Blood Collection. Blood samples were collected from all cows via tail vessel puncture on d 0 and $3(n=154)$. Blood samples also were collected in a subset of cows $(n=101)$ on $d-5,-4$, $-2,0,1,2$, and 3 . Samples were stored on ice and transported to the laboratory for storage at $5^{\circ} \mathrm{C}$ until serum was harvested by centrifugation $\left(1,200 \mathrm{x}\right.$ g). Sera samples were stored at $-15^{\circ} \mathrm{C}$ until 
they were assayed for progesterone concentration by radioimmunoassay using ImmuChem Double Antibody progesterone ${ }^{125} \mathrm{I}$ kits (Catalog \# 07-170105, MP Biomedicals LLC, Orangeburg, NY); inter- and intra-assay coefficients of variation for a low $(8.0$ and $4.8 \%)$ and high concentration pool (6.2 and 4.4\%), respectively.

Measurements. Several variables were recorded from the HW (time of initial and final standing event, number of standing events, and total standing time) and DM software (time when activity first met threshold, end of threshold activity, peak threshold activity, average count, peak count, average factor, and peak factor of threshold activity). Counts are the arbitrary units quantifying motion detected by the AMS. Factors are the standard deviation increase in motion from the previous $3 \mathrm{~h}$ of activity.

Statistical Analyses. Continuous outcome variables (measure of intensity of estrus including diameter of follicle on d 0 , interval of threshold activity [DM], average count and factor $[\mathrm{DM}]$, duration of estrus [HW], and mounting activity [HW]) were analyzed by procedure GLM of SAS (SAS Inst. Inc., Cary, NC) using a model of independent variables consisting of treatment (no CL + CIDR, CL + 2 CIDR, and CL only), parity (primiparous vs. multiparous), treatment by parity interaction, and BCS. Binomial data (occurrence of estrus and ovulation, pregnancy outcome, proportion of cows with progesterone $<0.5 \mathrm{ng} / \mathrm{mL} 72 \mathrm{~h}$ post $\mathrm{PGF}_{2 \alpha}$ injection) were analyzed by procedures GLIMMIX and LOGISTIC in SAS. The model consisted of the same variables as described previously for continuous variables. Concentrations of progesterone on $\mathrm{d}-5,-4,-2,0,1,2$, and 3 were analyzed by procedure MIXED in SAS including treatment, treatment within cow (testing error for treatment), day and treatment $\mathrm{x}$ day. 


\section{Experiment 2}

The objective of a second experiment was to determine if estrus expression was enhanced by supplementation with estradiol or testosterone (precursor to estradiol synthesis). Cows ( $\mathrm{n}=$ 203) were enrolled in a modified Double-Ovsynch protocol at $30 \pm 3$ DIM (Figure 2). Once-used progesterone inserts (CIDR) were placed intravaginally concurrent with the GnRH injection on d -7 and removed $7 \mathrm{~d}$ later when cows were administered i.m. 25 mg $\operatorname{PGF}_{2 \alpha}$ (d 0; Prostamate, Bayer HealthCare LLC, Shawnee Mission, KS). Cows were fitted with an AMS on d -7. On d 0, cows were fitted with a rump-mounted friction-activated patch (Estrotect heat detector patches, Rockway, Inc., Spring Valley, WI). At $24 \mathrm{~h}$ after $\mathrm{PGF}_{2 \alpha}, 203$ cows were assigned randomly to 3 treatments to receive: (1) $1 \mathrm{mg}$ of ECP $(\mathrm{n}=68)$; (2) $2 \mathrm{mg}$ of TP $(\mathrm{n}=68)$, or (3) control ( $\mathrm{n}=67)$ with no injection. At the same time as treatments were administered, all cows received a second i.m. injection of $25 \mathrm{mg} \mathrm{PGF} 2 \alpha$. Cows were inseminated after estrus was detected ( 8 to $12 \mathrm{~h}$ after activity threshold or patches were activated). Estrus was defined to have occurred when at least 1 ovarian follicle $\geq 10 \mathrm{~mm}$ was identified on $\mathrm{d} 0$ and progesterone was $\leq 0.5 \mathrm{ng} / \mathrm{mL}$ on d 3 (qualifying cows).

Ovarian Mapping. Transrectal ovarian ultrasonography (7.5-MHz linear-array transducer, Aloka 500V; Corometrics Medical Systems Inc., Wallingford, CT) was performed on $\mathrm{d}-7$ to determine the presence of a CL. Ovarian scanning was repeated on $\mathrm{d} 0$ and 4 to measure dominant follicle diameter and on $\mathrm{d} 11$ to determine ovulation after estrus expression.

Blood Collection. Blood samples were collected from all cows via tail vessel puncture on $\mathrm{d} 0,1,2$, and $3(\mathrm{n}=154)$. Samples were stored on ice and transported to the laboratory for storage at $5^{\circ} \mathrm{C}$ until serum was harvested by centrifugation $(1,200 \mathrm{x}$ g). Sera samples were stored at $-15^{\circ} \mathrm{C}$ until they were assayed for progesterone concentration by radioimmunoassay using 
ImmuChem Double Antibody progesterone 125I kits (Catalog \# 07-170105, MP Biomedicals LLC, Orangeburg, NY); inter- and intra-assay coefficients of variation for a low (7.5 and 4.0\%) and high concentration pool (5.3 and 3.8\%), respectively.

Concentrations of estradiol-17 $\beta$ were measured by RIA (Perry et al., 1991) with some modifications in blood serum collected on d 2,3, and 4 from a subset of cows $(\mathrm{n}=185)$. Blood serum before assay was extracted by using 10 volumes of methyl T-butyl ether (HPLC grade, Fisher Scientific, St. Louis, Mo). The radioligand $\left({ }^{125}\right.$ I-labeled $17 \beta$-estradiol; 1,500 to 2,000 $\mu \mathrm{Ci} / \mu \mathrm{g}$ ) was purchased from MP Biomedicals LLC (Solon, OH). Inter-and intra-assay coefficients of variation for a low (11.0 and 23.0\%) and high serum pool (7.7 and 11.1\%), respectively. Concentrations of testosterone were measured in selected samples, however concentrations were below the sensitivity of the radioimmunoassay.

Measurements. Several variables were recorded from the DM software (time when activity first met threshold, end of threshold activity, peak threshold activity, average count, peak count, average factor, and peak factor of threshold activity).

Statistical Analyses. Continuous outcome variables (measure of intensity of estrus including diameter of follicle on d 0 , interval of threshold activity [DM], average counts, and factors $[\mathrm{DM}]$ were analyzed by procedure GLM of SAS (SAS Inst. Inc., Cary, NC) using a model of independent variables consisting of treatment (ECP, TP, and control), parity (primiparous vs. multiparous), treatment by parity interaction, and BCS. Binomial data (occurrence of estrus and ovulation, pregnancy outcome, proportion of cows with progesterone $<$ $0.5 \mathrm{ng} / \mathrm{mL} 72 \mathrm{~h}$ post $\mathrm{PGF}_{2 \alpha}$ injection) were analyzed by procedures GLIMMIX and LOGISTIC in SAS. The model consisted of the same variables as described previously for continuous 
variables. Changes in concentrations of progesterone and estradiol on d $0,1,2$, and 3 were analyzed by procedure MIXED in SAS as described in experiment 1.

\section{RESULTS}

\section{Experiment 1}

Mean concentrations of progesterone in a subset of cows relative to the injection of $\mathrm{PGF}_{2 \alpha}$ to induce luteolysis are illustrated in Figure 3. On d -5 concentrations of progesterone for cows in $\mathrm{CL}$ only and $\mathrm{CL}+2 \mathrm{CIDR}$ treatments were greater $(P<0.05)$ compared with the no CL + CIDR treatment. Progesterone concentrations increased after CIDR insertion and differed among treatments $(P<0.01)$ from $\mathrm{d}-4$ through $\mathrm{d} 0$, with $\mathrm{CL}+2$ CIDR cows having the greatest concentrations of progesterone compared with CL only and no CL + CIDR cows. After PGF $2 \alpha$ was administered on $\mathrm{d} 0$, mean concentrations of progesterone decreased to $\leq 1 \mathrm{ng} / \mathrm{mL}$ by d 3 .

In all enrolled cows, concentrations of progesterone differed $(P \leq 0.05)$ on $\mathrm{d}-2$ and $\mathrm{d}-4$ among treatments before $\mathrm{PGF}_{2 \alpha}$, however, concentrations of progesterone decreased thereafter to $\leq 1 \mathrm{ng} / \mathrm{mL}$ and did not differ on $\mathrm{d} 3$ (Figure 4). In addition, average diameter of putative preovulatory follicle on d 0 was greater $(P \leq 0.01)$ in no $\mathrm{CL}+\mathrm{CIDR}$ cows compared with $\mathrm{CL}$ only and CL +2 CIDR treatments $(17.0 \pm 0.4 \mathrm{~mm}$ vs. $14.2 \pm 0.5 \mathrm{~mm}$ and $14.6 \pm 0.4 \mathrm{~mm})$, respectively.

Occurrence of estrus and ovulation for all enrolled cows is summarized in Table 1. As assessed by the AMS, occurrence of estrus ranged from 56 to $67 \%$, and of cows that expressed estrus, ovulation risk varied from 89 to $100 \%$ among treatments. As assessed by the pressuresensitive device, occurrence of estrus varied from 45 to $61 \%$, and of cows that expressed estrus, ovulation risk was $100 \%$ in all cows regardless of treatment. For all enrolled cows, estrus expression and ovulation risk did not differ among treatments. As parity increased, however, 
estrus expression and ovulation rate decreased $(P \leq 0.01)$. Furthermore, as BCS decreased, estrus expression and ovulation also decreased $(P \leq 0.01)$.

Occurrence of estrus and ovulation for qualifying cows (follicle $\geq 10 \mathrm{~mm}$ at $\mathrm{PGF}_{2 \alpha}$ injection and progesterone $\leq 0.5 \mathrm{ng} / \mathrm{mL} 72$ later) is summarized in Table 2. As assessed by the AMS, occurrence of estrus ranged from 61 to $77 \%$, and of qualifying cows that expressed estrus, ovulation risk ranged from 89 to $100 \%$ and did not differ among treatments. As determined by pressure-sensitive device, occurrence of estrus ranged from 50 to $71 \%$, and of qualifying cows that expressed estrus, ovulation risk was $100 \%$ and did not differ among treatments. Compared with multiparous cows, primiparous cows had greater $(P<0.01)$ estrus expression and ovulation risk. Furthermore, as BCS decreased, occurrence of estrus and ovulation also decreased.

Characteristics of estrus are summarized in Table 3 as assessed by the AMS and pressuresensitive device. As determined by the AMS, onset of estrus was detected earlier $(P<0.01)$ for cows in the no CL + CIDR treatment compared with CL only treatment. Duration of estrus (hours that activity was above threshold) quantified by the AMS, averaged between $11.0 \pm 1.0$ and $12.4 \pm 1.1 \mathrm{~h}$ among treatments. Although peak factor, as a measure of estrus intensity by the AMS, was greater $(P<0.05)$ for cows in the $\mathrm{CL}+2$ CIDR treatment compared with CL only, no other measures of estrus intensity (mean count, peak count, and mean factor) differed among treatments.

Based on the pressure-sensitive device, onset of estrus ranged from $59 \pm 5$ to $79 \pm 5 \mathrm{~h}$ among treatments (Table 3). Duration of estrus (interval between first and last recorded standing event) averaged between $4.6 \pm 0.8$ and $6.5 \pm 1.1 \mathrm{~h}$ and did not differ among treatments. Furthermore, various measures of estrus intensity (number and duration of standing events) did not differ among treatments. 
Pregnancy per AI was 56.7, 36.6, and $41.3 \%$ for CL only $(n=37)$, no CL + CIDR $(n=$ 37), and CL +2 CIDR $(n=32)$ treatments, respectively.

\section{Experiment 2}

Concentrations of progesterone in all cows $(n=203)$ enrolled in experiment 2 at the time of $\mathrm{PGF}_{2 \alpha}$ through $72 \mathrm{~h}$ after injection are illustrated in Figure 5. Mean concentrations of progesterone exceeded $5 \mathrm{ng} / \mathrm{mL}$ before the first of $2 \mathrm{PGF}_{2 \alpha}$ injections were administered and decreased to $\leq 0.5 \mathrm{ng} / \mathrm{mL}$ by $48 \mathrm{~h}$. Concentrations of estradiol relative to the initial injection of $\mathrm{PGF}_{2 \alpha}$ in a subset of cows $(\mathrm{n}=101)$ on $\mathrm{d} 2$ and 3 were greater $(P<0.01)$ in cows treated with ECP compared with TP and controls (Figure 6). In addition, average diameter of the preovulatory follicle ranged from $14.1 \pm 1$ to $14.4 \pm 0.3 \mathrm{~mm}$, but did not differ among all treatments.

Estrus expression and ovulation for all enrolled cows are summarized in Table 4. Estrus expression determined by AMS varied from 67 to $79 \%$ among treatments, and of the cows that expressed estrus, ovulation risk ranged from 90 to $96 \%$. More cows with friction-activated patches tended $(P=0.09)$ to activate in ECP cows compared with controls. Of the cows that expressed estrus as assessed by friction-activated patches, ovulation risk ranged from 90 to $100 \%$ among treatments.

Estrus expression and ovulation for qualifying cows are summarized in Table 5. As determined by the AMS, occurrence of estrus tended $(P=0.10)$ to be greater for ECP cows compared with the control. Of the qualifying cows that expressed estrus by the AMS, ovulation risk ranged from 90 to $100 \%$. More $(P<0.05) \mathrm{ECP}$ cows with friction-activated patches were detected in estrus compared with the control, and of qualifying cows identified in estrus, ovulation risk varied from 91 to $100 \%$ (Table 6). 
Characteristics of estrus assessed by the AMS are summarized in Table 6. Compared with controls, onset of estrus from time of ECP or TP treatment occurred earlier $(P<0.05)$ for ECP cows and tended $(P<0.10)$ to be earlier for TP cows. Average interval from CIDR removal to onset of estrus ranged from $50 \pm 5$ to $58 \pm 5 \mathrm{~h}$ among treatments. Duration of estrus averaged between $9.9 \pm 0.8$ and $10.3 \pm 0.7 \mathrm{~h}$ among treatments. Although greater $(P<0.05)$ average peak counts suggested greater intensity of estrus in ECP cows compared with controls, other measures of estrus intensity (mean count, mean factor, and peak factor) did not differ among treatments.

Pregnancy risk resulting from AI was 40.6, 32.7, and 29.4\% for the ECP $(n=62)$, TP (n $=52)$, and control $(\mathrm{n}=51)$ cows, respectively.

\section{Efficiency and Accuracy of Detected Estrus}

Efficiency and accuracy of the 3 methods employed to detect estrus were compared in all qualifying cows (cows that should have been in estrus based on the presence of a follicle $\geq 10$ $\mathrm{mm}$ at the time of $\mathrm{PGF}_{2 \alpha}$ and progesterone $\leq 0.5 \mathrm{ng} / \mathrm{mL} 72 \mathrm{~h}$ later). The proportions of enrolled cows meeting these criteria that were detected in estrus (efficiency), ovulated, or both (accuracy) are summarized in Table 7. Efficiency of detected estrus ranged from 62 to $74 \%$. Ovulation risk (accuracy of detected estrus) for the cows detected by the AMS, pressure-sensitive devices, and friction-activated patches were 94,96 , and $94 \%$, respectively. Of the 26 to $29 \%$ of cows that did not express estrus, ovulation risk ranged from 60 to $76 \%$ in the absence of estrus.

\section{DISCUSSION}

The current studies evaluated if: 1) altering concentrations of progesterone before inducing luteolysis; or 2) exposing cows to ECP or TP after luteolysis was induced would increase the occurrence and intensity of estrus. It has been reported that progesterone treatment increased estradiol receptor concentrations in the ventromedial hypothalamus of the ewe (Caraty 
and Skinner, 1999), suggesting a possible priming effect of progesterone in the brain for various estradiol-mediated functions. The treatments implemented in experiment 1 caused concentrations of progesterone to differ by $24 \mathrm{~h}$ and to remain different until $24 \mathrm{~h}$ post-PGF $2 \alpha$ injection. In experiment 1, cows within the no CL + CIDR treatment may have come to estrus earlier compared with those cows bearing CL because their preovulatory follicles were larger and progesterone clearance in the absence of a CL occurred more quickly upon removal of the exogenous progesterone insert. Observed larger follicles in the no CL + CIDR cows are consistent with previous reports of follicles growing faster and becoming larger in a lesser rather than greater progesterone environment (Savio et al., 1993; Cerri et al., 2011).

Previous research has shown that the detection efficiency of identifying estrus is improved when cows are treated with progesterone (Carrick and Shelton, 1969; Stevenson et al., 1977). Postpartum dairy cows initiating the Ovsynch protocol without a CL and treated with 2 CIDR inserts were reported to have greater pregnancy risk than untreated herd mates and similar fertility as CL-bearing contemporary controls starting Ovsynch in diestrus (Bisinotto et al., 2013; 2015). Peak factor, used to quantify estrus intensity, was greater for CL +2 CIDR cows compared with CL only in experiment 1 . An increase in estrus intensity supports the idea that progesterone priming may affect the threshold at which estradiol stimulates the GnRH surge (Caraty and Skinner, 1999). This increase in intensity of estrus may have been detected in the CL +2 CIDR cows because of their greater circulating progesterone concentrations. Circulating concentrations of progesterone are determined by two factors: 1) secretion rate of progesterone by the CL; and 2) metabolic clearance rate via hepatic enzymatic functions. Concentrations of progesterone range from 4.0 to $5.8 \mathrm{ng} / \mathrm{mL}$ during mid diestrus in lactating dairy cows (Sartori et al., 2004; Bisinotto et al., 2013); however, a single progesterone insert achieves only $20 \%$ of the 
circulating progesterone concentrations of mid diestrus in high-producing dairy cows (Cerri et al., 2009; Bisinotto et al., 2013). Previous research has shown in sub fertile dairy cows that metestrual concentrations of progesterone increased more slowly compared with heifers after estrus (Shelton et al., 1990; Inskeep and Dailey, 2005). Studies have shown that high-producing dairy cows have elevated metabolic clearance rates for steroids compared with non-lactating dairy cows (Sangsritavong et al., 2002; Wiltbank et al., 2006).

The action of estradiol on the hypothalamus in the relative absence of progesterone is responsible for estrus (Allrich, 1994). In a previous study, substituting ECP for GnRH in a TAI protocol, resulted in more cows in estrus after the induction of luteolysis (Stevenson et al., 2004). Estradiol concentrations were greater in the ECP cows than in the non-estradiol treated cows by $24 \mathrm{~h}$ after treatment, and subsequently, ECP cows came to estrus earlier than control cows. Peak count, used to quantify estrus intensity, was greater for ECP compared with control cows indicating the causative effects of estradiol. Although studies have examined metabolic clearance of progesterone (Lucy, 2001; Rhinehart et al., 2009; Lemley et al., 2010), it has been hypothesized that insufficient estradiol produces inadequate stimulation of the hypothalamus resulting in a lack of behavioral estrus (Pereira et al., 2016). A previous study determined metabolic clearance rate of estradiol per metabolic weight for a fasted compared with a well fed dairy cow to be 0.23 vs. $0.36 \mathrm{~L}$ per min per $\mathrm{kg} \mathrm{BW}^{0.75}$ (Sangsritavong et al., 2002), which agreed with data in gilts (0.11 to $0.24 \mathrm{~L}$ per min per $\mathrm{kg} \mathrm{BW}^{0.75}$; Christenson et al., 1985). Experiment 2 demonstrated that cows supplemented with ECP had increased circulating concentrations of estradiol during $48 \mathrm{~h}$ post treatment as well as increased estrus expression compared with control cows. Further research is warranted to investigate how metabolic clearance rate affects concentrations of estradiol and subsequent estrus expression. 
Reports indicate that fertility is increased in cows that express estrus at fixed-time AI (Galvão et al., 2004; Pereira et al., 2014; 2016). Estrus expression also was associated with better synchronization and greater pregnancy per AI from 32 to $60 \mathrm{~d}$ after AI (Pereira et al., 2016). Increased estrus expression after treatment with ECP in experiment 2 is in agreement with previous research (Souza et al., 2009; Pereira et al., 2016). According to the 2-cell, 2gonadotropin model, cholesterol is converted to progesterone and then to androstenedione by theca cells of the follicle. Androstenedione is then transported to granulosa cells where, under the influence of $\mathrm{P} 450_{\text {arom, }}$, it is converted to estradiol-17ß (Hansel and Convey, 1983). Part of experiment 2 was to determine if the limiting factor for estrus expression was insufficient conversion of precursor steroid hormones to estradiol. One mg dose of TP injected on alternate days was adequate to induce elevated blood testosterone concentrations in ovariectomized cows (Kiser et al., 1977). If a greater dose of TP had been used, perhaps sufficient estradiol production may have occurred in cows treated with TP and greater expression of estrus may have occurred.

Cows in estrus express more mounting activity in pastures or dry lots than in free-stall or tie-stall housing systems (De Silvia et al., 1981; Palmer et al., 2010). Previous research reported cows observed on a dirt surface have longer durations of estrus and have more total standing events compared with cows on a dry, grooved concrete surface (Helmer and Britt, 1985). When given the option by experimental design, cows in estrus preferred to spend $73 \%$ of their estrual periods on dirt rather than concrete surfaces and their mounting activity on dirt was increased 3to 15-times compared with concrete (Vailes and Britt, 1990). Given many dairy facilities are concrete confinement operations, secondary signs of estrus are a significant tool for estrus detection. 
Increased physical activity is highly correlated with estrus. Activity during estrus increased by $400 \%$ in $93 \%$ of estrous periods (Kiddy, 1977), which has formed the basis for developing many pedometer and accelerometer devices on the market for dairy producers today (Stevenson et al., 2014). Quantifying pedometry associated with estrus has served as a means of estrus detection as early as the 1970s (Roelofs et al., 2010).). The current study used a market available AMS to determine estrus and was compared with a pressure-sensitive device and friction-activated patch. In experiments 1 and 2, none of the devices employed were superior to the others in detecting more cows in estrus. Estrus-detection risk ranged from 61.8 to $73.9 \%$ for cows in experiment 1 and 2, which is in agreement with earlier findings. Previous research determined that approximately two-thirds of cows considered properly synchronized (follicle diameter $\geq 10 \mathrm{~mm}$ at time of first GnRH injection, and concentrations of progesterone $\geq 1 \mathrm{ng} / \mathrm{mL}$ at the time of $\mathrm{PGF}_{2 \alpha}$ and $\leq 1 \mathrm{ng} / \mathrm{mL} 48 \mathrm{~h}$ after $\mathrm{PGF}_{2 \alpha}$ ) would be inseminated based on an AMS (Valenza et al., 2012).

Previous research also determined that the proportion of cows detected in estrus did not differ between an AMS or Heatmount detector (Valenza et al., 2012). The present studies found that of cows not detected in estrus by any method, 60 to $76 \%$ subsequently ovulated. Our results are consistent with similar findings of non-detected cows (by AMS and Heatmount detectors) subsequently ovulating between 53 and $65 \%$ of the time (Valenza et al., 2012). Both studies support the value of various estrus-detection tools for herds that are not achieving estrusdetection risks in excess of 60 to $70 \%$. Herds that are achieving estrus-detection risks equal to or greater than what was demonstrated in the present study will not likely find added value of employing any AMS that does not significantly improve their current estrus-detection risk. The AMS have greater value than static one-time use methods such as patches and standard chalk or 
paint rubs because of the time-date information and 24-h surveillance provided via the AMS software. Furthermore, not demonstrated by the present experiments, is the value of identifying the first return to estrus that occurs subsequent to AI to decrease further inter-insemination intervals.

\section{CONCLUSIONS}

Only ECP successfully induced more cows in estrus, but proportions of cows detected never exceeded $80 \%$. Given the large proportion of cows ovulating in the absence of estrus, further research is warranted to determine if conception is achievable by inseminating cows not detected in estrus at some time after $\mathrm{PGF}_{2 \alpha}$-induced luteolysis. An AMS is likely an appropriate tool for herds achieving less than the estrus-detection risk achieved in these experiments (60 to $70 \%$ ). Although efficiency and accuracies of the 3 estrus expression methods employed did not differ, the AMS and pressure-sensitive rump-mounted pressure detectors offer continuous monitoring of activity independent of visual assessment of friction-activated patches by herd personnel and potentially offer greater surveillance options in all cows.

\section{ACKNOWLEDGMENTS}

I gratefully acknowledge Kansas State University Dairy Teaching and Research Center manager M. V. Scheffel and his staff for all their help. I thank W. S. Fausnett for performing the radioimmunoassays for progesterone and L. Hill for assistance with sample collection. Donations of CIDR inserts, Lutalyse, and Factrel by Zoetis Animal Health; Prostamate by Bayer, Estrotect patches from Rockway, Inc. are gratefully acknowledged.

\section{REFERENCES}

Allrich, R. D. 1994. Symposium: estrus, new devices, and monitoring; endocrine and neural control of estrus in dairy cows. J. Dairy Sci. 77:2738-2744. 
Bisinotto, R. S., R. C. Chebel, and J. E. Santos. 2010. Follicular wave of the ovulatory follicle and not cyclic status influences fertility of dairy cows. J. Dairy Sci. 93:3578-3587.

Bisinotto, R. S., E. S. Ribeiro, F. S. Lima, N. Martinez, L. F. Greco, L. F. S. P. Barbosa, P. P. Bueno, L. F. S. Scagion, W. W. Thatcher, and J. E. P. Santos. 2013. Targets progesterone supplementation improves fertility in lactating dairy cows without a corpus luteum at the initiation of the timed artificial insemination protocol. J. Dairy Sci. 96:2214-2225.

Britt, J. H., R. G. Scott, J. D. Armstrong, and M. D. Whitacre. 1986. Determinants of estrous behavior in lactating Holstein cows. J. Dairy Sci. 69:2195-2202.

Caraty, A., and D. C. Skinner. 1999. Progesterone priming is essential for the full expression of the positive feedback effect of estradiol in inducing the preovulatory gonadotropin releasing hormone surge in the ewe. Endocrinology 140:165-170.

Caraviello, D. Z., K. A. Weigel, P. M. Fricke, M. C. Wiltbank, M. J. Florent, N. B. Cook, K. V. Nordlund, N. R. Zwald, and C. L. Rawson. 2006. Survey of management practices on reproductive performance of dairy cattle on large US commercial farms. J. Dairy Sci. $89: 4723-4735$.

Carrick, M. J., and J. N. Shelton. 1969. Estrogen-progesterone relationships in induction of estrus in spayed heifers. J. Endocrinol. 44:99-109.

Cerri, R. L. A., R. C. Chebel, F. Rivera, C. D. Narciso, R. A. Oliveira, W. W. Thatcher, and J. E. P. Santos. 2011. Concentration of progesterone during the development of the ovulatory follicle:1. Ovarian and embryonic responses. J. Dairy Sci. 94:3342-3351.

Cerri, R.L.A., H. M. Rutigliano, R. G. Bruno, and J. E. P. Santos. 2009. Progesterone concentration, follicular development and induction of cyclicity in dairy cows receiving intravaginal progesterone insets. Anim. Reprod. Sci. 110:56-70. 
Christenson, R. K., J. J. Ford, and D. A. Redmer. 1985. Metabolic clearance and production rates of estradiol and progesterone during pubertal and postpubertal development in gilts. J. Reprod. Fertil. 75:247-253.

De Silva, A. W. N. A., G. W. Anderson, F. C. Gwazdauskas, M. L. McGilliard, and J. A. Lineweaver. 1981. Interrelationships with estrous behavior and conception in dairy-cattle. J. Dairy Sci. 64:2409-2418.

Egger-Danner, C., J. B. Cole, J. E. Pryce, N. Gengler, B. Heringstad, A. Bradley, and K. F. Stock. 2015. Invited review: overview of new traits and phenotyping strategies in dairy cattle with a focus on functional traits. Animal 9:191-207.

Favre-Nys, C., and G. B. Martin. 1993. Analysis of the hormonal control of female sexual behavior and the preovulatory LH surge in the ewe: roles of quantity of estradiol and duration of its presence. Horm. Behav. 27:108-121.

Fricke, P. M., P. D. Carvalho, J. O. Giordano, A. Valenza, G. Lopes Jr., and M. C. Amundson. 2014. Expression and detection of estrus in dairy cows: the role of new technologies. Animal $8: 134-143$.

Galvão, K. N., J. E. Santos, S. O. Juchem, R. L. Cerri, A. C. Coscioni, and M. Villaseñor. 2004. Effect of addition of a progesterone intravaginal insert to a timed insemination protocol using estradiol cypionate on ovulation rate, pregnancy rate, and late embryonic loss in lactating dairy cows. J. Anim. Sci. 82:3508-3517.

Hansel, W., and E. M. Convey. 1983. Physiology of the estrous cycle. J. Anim. Sci. 57:404-424. Helmer, S. D., and J. H. Britt. 1985. Mounting behavior as affected by stage of estrous cycle in Holstein heifers. J. Dairy Sci. 68:1290-1296. 
Inskeep, E. K., and R. A. Dailey. 2005. Embryonic death in cattle. Vet. Clin. Food Anim. 21:437-461.

Katz, L. S., E. A. B. Oltenacu, and R. H. Foote. 1980. The behavioral responses in ovariectomized cattle to either estradiol, testosterone, androstenedione, or dihydrotestosterone. Horm. Behav. 14:224-235.

Kiddy, C. A. 1977. Variation in physical activity as an indication of estrus in dairy cows. J. Dairy Sci. 60:235-243.

Kiser, T. E., J. H. Britt, and H. D. Ritchie. 1977. Testosterone treatment of cows for use in detection of estrus. J. Anim. Sci. 44:1030-1035.

Lemley, C. O., T. A. Wilmoth, L. R. Tager, K. M. Krause, and M. E. Wilson. 2010. Effect of a high cornstarch diet on hepatic cytochrome P450 2C and 3A activity and progesterone halflife in dairy cows. J. Dairy Sci. 93:1012-1021.

Lewis, G. S., and S. K. Newman. 1984. Changes throughout estrous cycles of variables that might indicate estrus in dairy cows. J. Dairy Sci. 67:146-152.

Lopez, H., D. Z. Caraviello, L. D. Satter, P. M. Fricke, and M. C. Wiltbank. 2005. Relationship between level of milk production and multiple ovulations in lactating dairy cows. J. Dairy Sci. 88:2783-93.

Lovendahl, P., M., and G. G. Chagunda. 2010. On the use of physical activity monitoring for estrus detection in dairy cows. J. Dairy Sci. 93:249-259.

Lucy, M. C. 2001. Reproductive loss in high producing dairy cattle: Where will it end? J. Dairy Sci. 84:1277-1293.

Palmer, M. A., G. Olmos, L. A. Boyle, and J. F. Mee. 2010. Estrus detection and estrus characteristics in housed and pastured Holstein-Friesian cows. Theriogenology 74:255-264. 
Pereira, M. H. C., A. D. Rodrigues, R. J. De Carvalho, M. C. Wiltbank, and J. L. Vasconcelos. 2014. Increasing length of an estradiol and progesterone timed artificial insemination protocol decreases pregnancy loss in lactating dairy cows. J. Dairy Sci. 97:1454-1464.

Pereira, M. H. C., M. C. Wiltbank, and J. L. M. Vasconcelos. 2016. Expression of estrus improves fertility and decreases pregnancy losses in lactating dairy cows that receive artificial insemination or embryo transfer. J. Dairy Sci. 99:1-11.

Rhinehart, J. D., M. J. Starbuck-Clemmer, J. A. Flores, R. A. Milvae, J. Yao, D. H. Poole, and E. K. Inskeep. 2009. Low peripheral progesterone and late embryonic/early fetal loss in suckled beef and lactating dairy cows. Theriogenology 71:480-490.

Roelofs, J., F. López-Gatius, R. H. F. Hunter, F. J. C. M. van Eerdenburg, and C. Hazen. 2010. When is a cow in estrus? Clinical and practical aspects. Theriogenology 74:327-344.

Saint-Dizier, M., and S. Chastant-Maillard. 2012. Towards an automated detection of oestrus in dairy cattle. Journal of reproduction in domestic. Animal 47:1056-1061.

Sangsritavong, S., D. K. Combs, R. Sartori, L. E. Armentano, and M. C. Wiltbank. 2002. High feed intake increases liver blood flow and metabolism of progesterone and estradiol-17 $\beta$ in dairy cattle. J. Dairy Sci. 85:2831-2842.

Sartori, R., J. M. Haughian, R. D. Shaver, G. J. M. Rosa, and M. C. Wiltbank. 2004. Comparison of ovarian function and circulating steroids in estrous cycles of Holstein heifers and lactating cows. J. Dairy Sci. 87:905-920.

Savio, J. D., W. W. Thatcher, G. R. Morris, K. Entwistle, M. Drost, and M. R. Mattiacci. 1993. Effects of induction of low plasma progesterone concentrations with a progesterone-releasing intravaginal device on follicular turnover and fertility in cattle. J. Reprod. Fertil. 98:77-84. 
Sellars, C. B., J. C. Dalton, R. Manzo, J. Day, and A. Ahmadzadeh. 2006. Time and incidence of ovulation and conception rates after incorporating estradiol cypionate into a timed artificial insemination protocol. J. Dairy Sci. 89:620-626.

Senger, P. L. 1994. The estrus detection problem: new concepts, technologies, and possibilities. J. Dairy Sci. 77:2745-53.

Shelton, K., M. F. Gayerie de Abreu, M. G. Hunter, T. J. Parkinson, and G. E. Lamming. 1990. Luteal inadequacy during the early luteal phase of sub fertile cows. J. Reprod. Fertil. 90:1-10.

Silper, B. F., A. M. L. Madureira, M. Kaur, T. A. Burnett, and R. L. A. Cerri. 2015. Short communication: comparison of estrus characteristics in Holstein heifers by 2 activity monitoring systems. J. Dairy Sci. 98:3158-65.

Souza, A. H., S. Viechnieski, F. A. Lima, F. F. Silva, R. Araújo, G. A. Bó, M. C. Wiltbank, and P. S. Baruselli. 2009. Effects of equine chorionic gonadotropin and type of ovulatory stimulus in a timed-AI protocol on reproductive responses in dairy cows. Theriogenology $72: 10-21$.

Stevenson, J. S., and J. H. Britt. 1977. Detection of estrus by three methods. J. Dairy Sci. 60:1994-1998.

Stevenson, J. S., S. L. Hill, R. L. Nebel, and J. M. DeJarnette. 2014. Ovulation timing and conception risk after automated activity monitoring in lactating dairy cows. J. Dairy Sci. 97:4296-4308.

Stevenson, J. S., S. M. Tiffany, and M. C. Lucy. 2004. Use of estradiol cypionate as a substitute for GnRH in protocols for synchronizing ovulation in dairy cattle. J. Dairy Sci. 87:3289-3305. 
Vailes, L. D., and J. H. Britt. 1990. Influence of footing surface on mounting and other sexual behaviors of estrual Holstein cows. J. Anim. Sci. 68:2333-2339.

Valenza, A., J. O. Giordano, G. Lopes Jr., L. Vincenti, M. C. Amundson, and P. M. Fricke. 2012. Assessment of an accelerometer system for detection of estrus and treatment with gondadotropin-releasing hormone at the time of insemination in lactating dairy cows. J. Dairy Sci. 95:7115-7127.

Wiltbank, M. C., H. Lopez, R. Sartori, S. Sangsritavong, and A. Gumen. 2006. Changes in reproductive physiology of lactating dairy cows due to elevated steroid metabolism. Theriogenology 65:17-29.

Yaniz, J. L., P. Santolaria, A. Giribet, and F. Lopez-Gatius. 2006. Factors affecting walking activity at estrus during postpartum period and subsequent fertility in dairy cows. Theriogenology 66:1943-1950. 


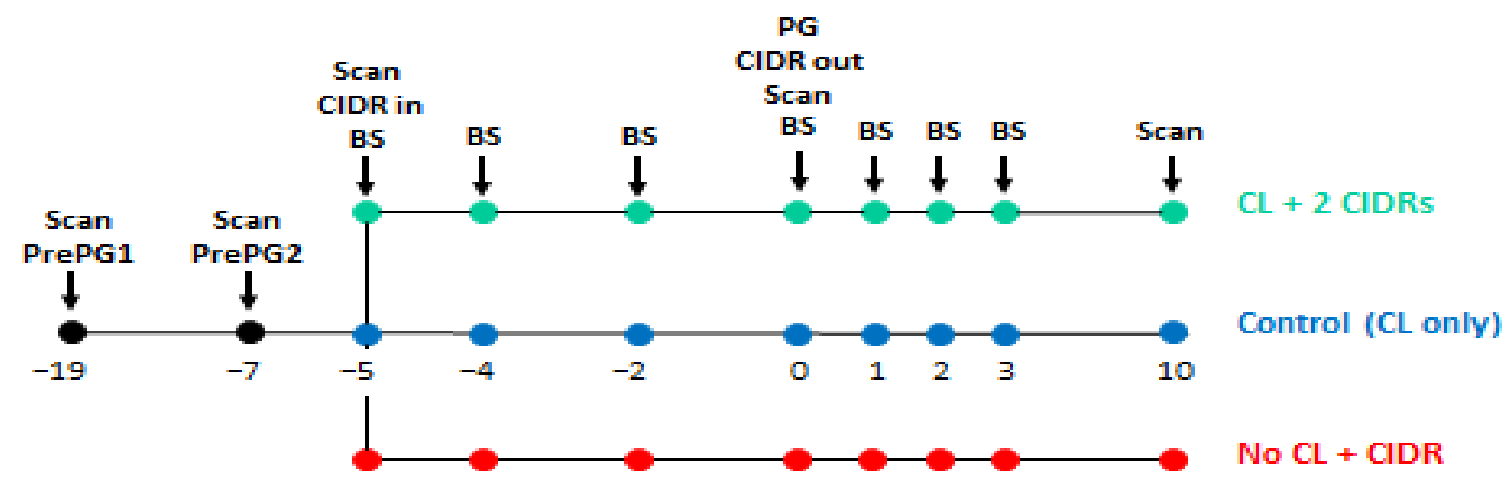

Figure 1. Experiment 1. On d-19, cows were treated with $\mathrm{PGF}_{2 \alpha}(\mathrm{PrePG} 1)$ and ovaries were scanned to determine follicle and CL location. On $d-7$ ovaries were scanned to determine the presence of a CL. Based on the CL status of cows on $d-7$, cows were preliminarily assigned randomly to treatment. Those cows assigned to the no CL + CIDR treatment received an injection of $\mathrm{PGF}_{2 \alpha}$ on $\mathrm{d}-7$ (PrePG2). Ovarian scans were performed on $\mathrm{d}-5$ to determine the presence of a CL, cows were assigned randomly to 3 treatments: (1) CL +2 CIDR (cows with a CL and 2 CIDR inserts); (2) CL only (cows with only $1 \mathrm{CL}$, control group); and (3) no CL + CIDR (cows without a CL and 1 CIDR insert). An automated monitoring system (AMS) and rump-mounted pressure sensitive device were fitted to each cow. On d 0 an injection of $\mathrm{PGF}_{2 \alpha}$ (PG) was administered to induce luteolysis, CIDR inserts were removed, and size of the dominant follicle was determined by ultrasound examination. Estrus activities were assessed during $7 \mathrm{~d}$ post $\mathrm{PGF}_{2 \alpha}$ injection via the AMS and pressure sensitive device. Blood samples were collected from a subset of cows $(\mathrm{n}=101)$ on $\mathrm{d}-5,-4,-2,0,1$, and, 2 , and from all cows $(\mathrm{n}=$ 154) on $\mathrm{d} 0$ and 3 . Ovarian scans were performed on $\mathrm{d} 10$ to determine ovulation. $\mathrm{CIDR}=$ progesterone-impregnated controlled internal drug release insert. 


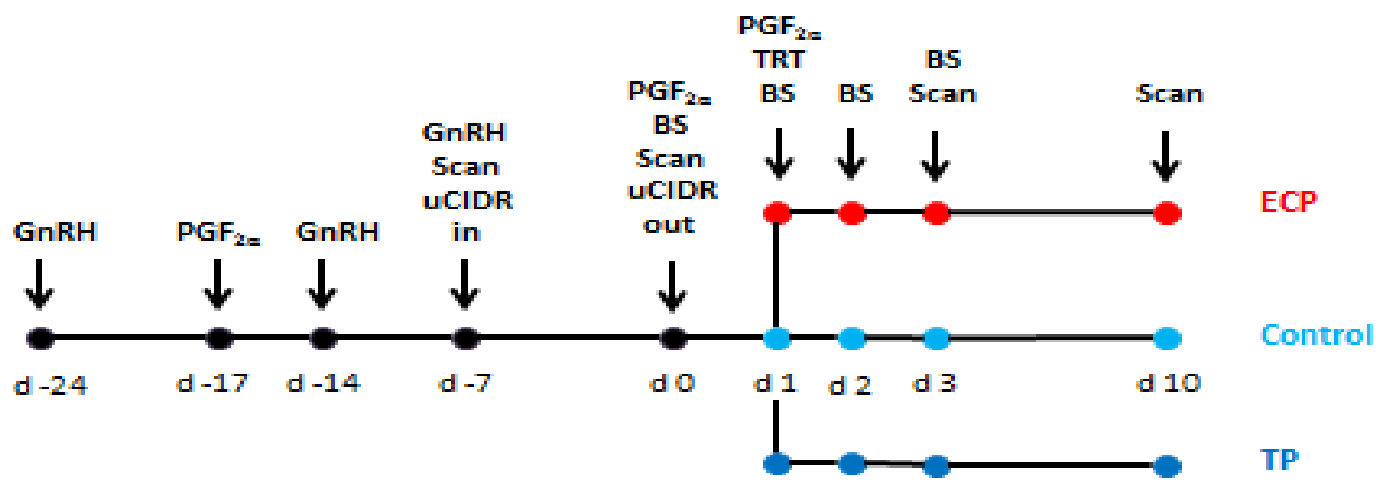

Figure 2. Experiment 2. Ovulation was synchronized with $\mathrm{GnRH}(\mathrm{d}-24), \mathrm{PGF}_{2 \alpha}(\mathrm{d}-17)$, and GnRH $(\mathrm{d}-14)$ before cows were exposed to a progesterone insert and concurrent GnRH injection on $\mathrm{d}-7$. Inserts were removed, ovarian structures were mapped, and $\mathrm{PGF}_{2 \alpha}$ was administered on $\mathrm{d} 0$. Cows received a second injection of $\mathrm{PGF}_{2 \alpha}$ on $\mathrm{d} 1$ and were assigned randomly to 3 treatments (TRT; d 1): $1 \mathrm{mg} \mathrm{ECP,} 2 \mathrm{mg}$ TP, or a control with no injection. Blood samples (BS) were collected from all cows $(\mathrm{n}=204)$ on $\mathrm{d} 0,1,2$, and 3 . Ovarian scans were performed on d 10 to determine ovulation. $\mathrm{uCIDR}=$ once-used progesterone-impregnated controlled internal drug release insert. 


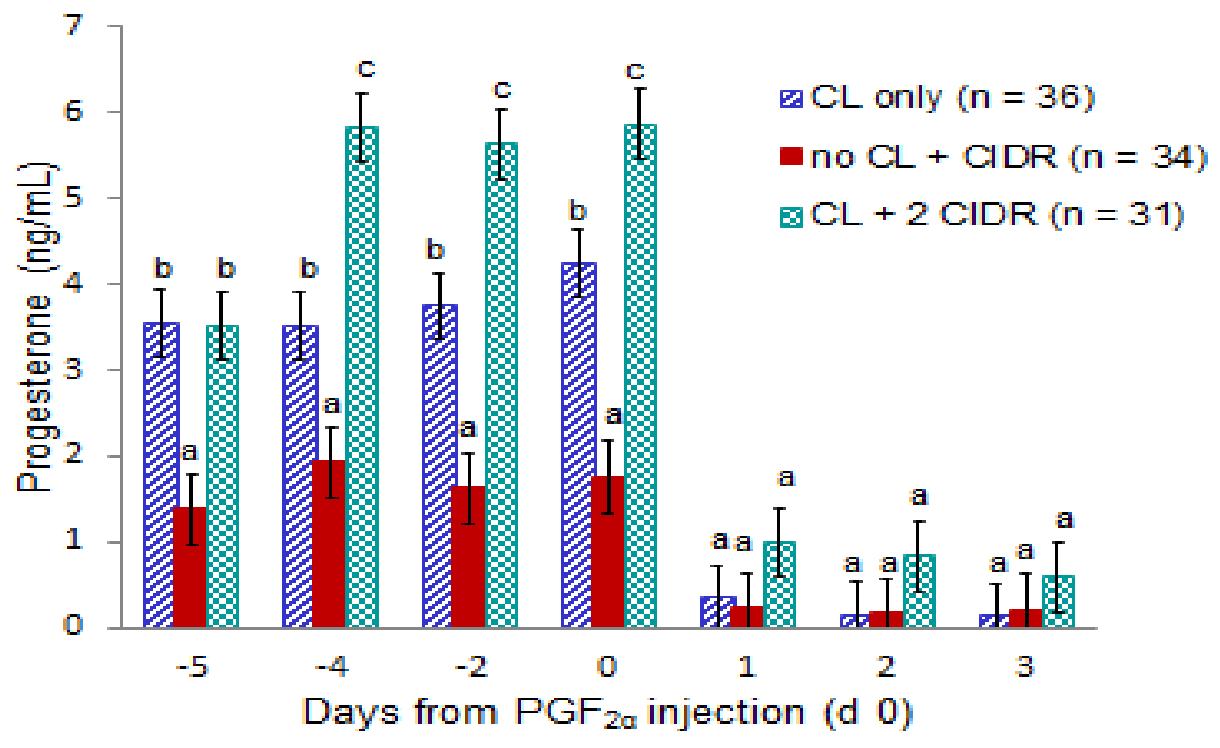

Figure 3. Mean $( \pm \mathrm{SE})$ concentrations of progesterone relative to injection of $\mathrm{PGF}_{2 \alpha}(\mathrm{d} 0)$ for all cows assigned to 3 treatments on $d-5$ (experiment 1): (1) CL only; (2) no CL + CIDR insert for $5 \mathrm{~d}$; or (3) CL $+2 \mathrm{CIDR}=$ the presence of a CL and 2 CIDR inserts for $5 \mathrm{~d}$. On d 0, CIDR inserts were removed and all cows received $\mathrm{PGF}_{2 \alpha}$. Least squares means bearing different letters within day differ $(P<0.05)$. Error bars represent SEM. 


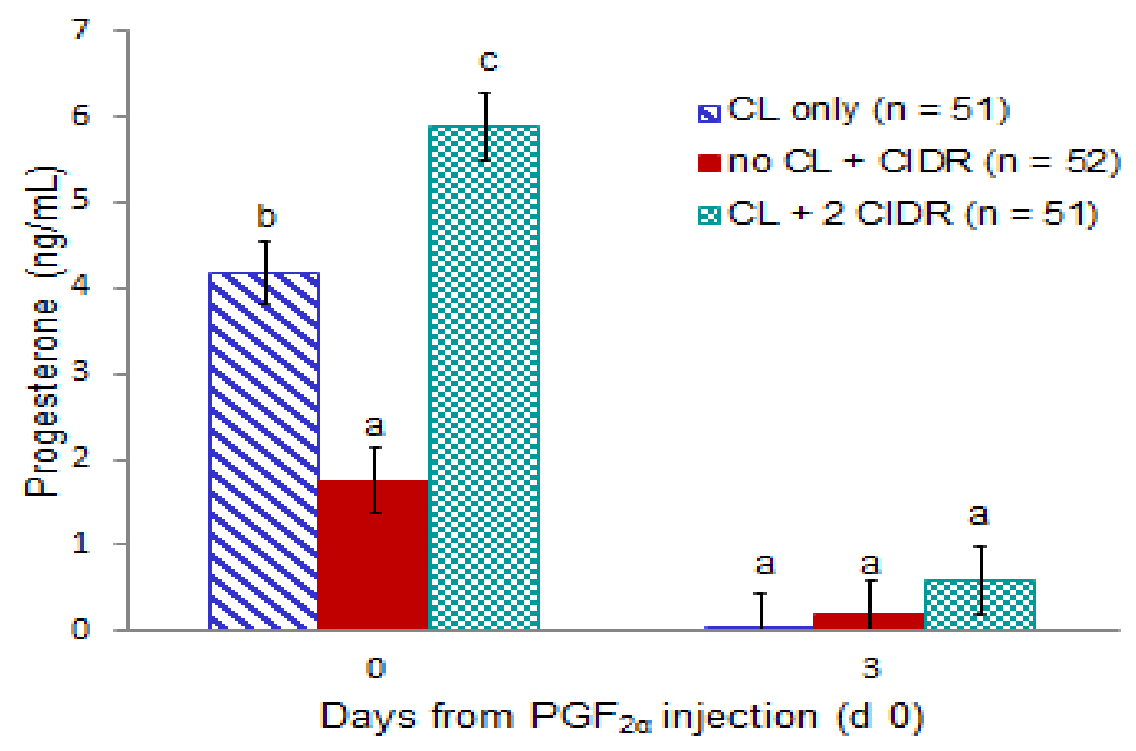

Figure 4. Mean $( \pm \mathrm{SE})$ concentrations of progesterone relative to injection of $\mathrm{PGF}_{2 \alpha}(\mathrm{d} 0)$ and 72 $\mathrm{h}$ later for all cows in 3 treatments on $\mathrm{d}-5$ (experiment 1): (1) $\mathrm{CL}$ only; (2) no CL + CIDR $=\mathrm{CL}$ + CIDR insert for $5 \mathrm{~d}$; or (3) CL + 2 CIDR inserts for $5 \mathrm{~d}$. On d 0 CIDR inserts were removed and all cows received $\mathrm{PGF}_{2 \alpha}$. Least squares means bearing different letters within day differ $(P<$ 0.05). Error bars represent SEM. 


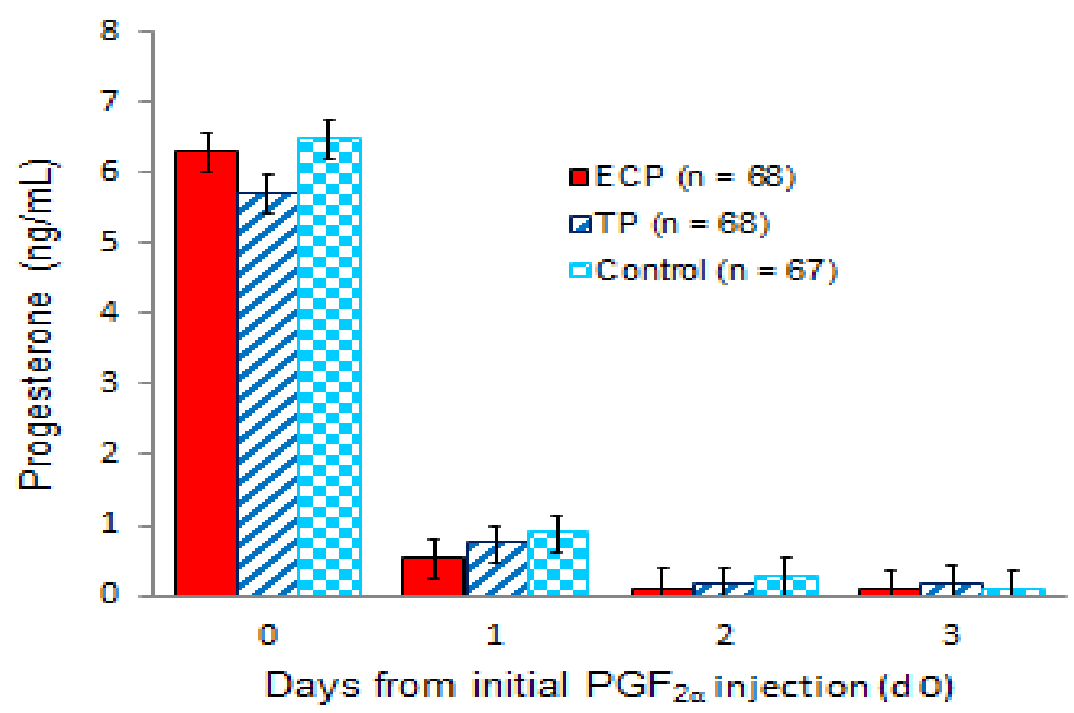

Figure 5. Mean ( $\pm \mathrm{SE})$ concentrations of progesterone relative to initial injection of $\mathrm{PGF}_{2 \alpha}(\mathrm{d} 0)$ for cows assigned to 3 treatments administered on $\mathrm{d} 1$ (experiment 2): (1) $\mathrm{ECP}=1 \mathrm{mg}$ estradiol cypionate; (2) TP = $2 \mathrm{mg}$ testosterone propionate; or control = no treatment injection. All cows received a second injection of $\mathrm{PGF}_{2 \alpha}$ on $\mathrm{d} 1$. Error bars represent SEM. 


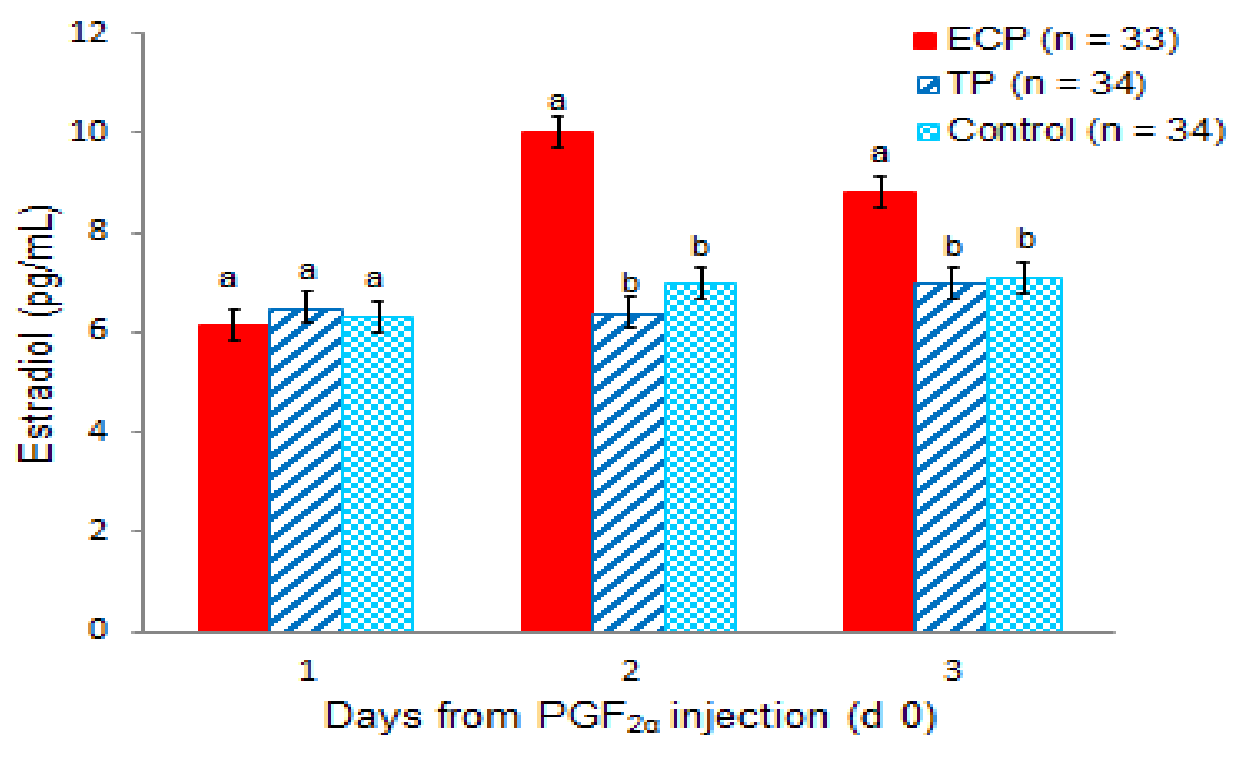

Figure 6. Mean ( \pm SE) concentrations of estradiol relative to initial $\mathrm{PGF}_{2 \alpha}$ injection $(\mathrm{d} 0)$ for cows assigned to 3 treatments administered on $\mathrm{d} 1$ (experiment 2): (1) ECP = $1 \mathrm{mg}$ i.m. estradiol cypionate; (2) TP = $2 \mathrm{mg}$ i.m. testosterone propionate; (3) Control = no treatment injection; (d 1). All cows received a second injection of $\mathrm{PGF}_{2 \alpha}$ on $\mathrm{d} 1$. Least squares means bearing different letters within day differ $(P<0.05)$. Error bars represent SEM. 
Table 1. Occurrence of estrus and ovulation in all cows fitted with an activity monitoring system (AMS) and a pressure sensitive device in experiment $1^{1}$

\begin{tabular}{lccc}
\hline & \multicolumn{3}{c}{ Treatment $^{2}$} \\
\cline { 2 - 4 } Item & CL only & no CL + CIDR & CL + 2 CIDR \\
\hline AMS & $62.9(51)$ & $66.9(52)$ & $56.3(51)$ \\
Estrus expression ${ }^{3}, \%$ & $100(33)$ & $100(34)$ & $89.3(28)$ \\
Estrus and ovulation ${ }^{4}, \%$ & & $61.3(52)$ & $45.2(51)$ \\
Pressure-sensitive device & $56.2(51)$ & $100(32)$ & $100(23)$ \\
Estrus expression ${ }^{3}, \%$ & $100(30)$ & & \\
Estrus and ovulation ${ }^{4}, \%$ & & \\
${ }^{1}$ All enrolled cows. & & \\
${ }^{2}$ CL only; no CL + CIDR = CL + CIDR insert (d 0) for 5 d; or CL + 2 CIDR inserts (d 0) for 5 \\
d. On d 0 CIDR inserts were removed and all cows received PGF $2 \alpha$. \\
${ }^{3}$ Percentage of cows expressing activity assessed by AMS or pressure-sensitive patches. \\
${ }^{4}$ Percentage of cows that ovulated subsequent to detection of estrus.
\end{tabular}


Table 2. Occurrence of estrus and ovulation in qualifying cows fitted with an activity monitoring system (AMS) and a pressure sensitive device in experiment $1^{1}$

\begin{tabular}{|c|c|c|c|}
\hline \multirow[b]{2}{*}{ Item } & \multicolumn{3}{|c|}{ Treatment $^{2}$} \\
\hline & CL only & no CL+ CIDR & $\mathrm{CL}+2 \mathrm{CIDR}$ \\
\hline AMS & & $\%(n)$ & \\
\hline Estrus expression ${ }^{3}, \%$ & $76.6(39)$ & $72.1(46)$ & $61.2(46)$ \\
\hline Estrus and ovulation ${ }^{4}, \%$ & $100(30)$ & $100(32)$ & $88.9(27)$ \\
\hline \multicolumn{4}{|l|}{ Pressure-sensitive device } \\
\hline Estrus expression ${ }^{3}, \%$ & $63.7(39)$ & $70.7(46)$ & $50.4(46)$ \\
\hline Estrus and ovulation ${ }^{4}, \%$ & $100(26)$ & $100(32)$ & $100(23)$ \\
\hline \multicolumn{4}{|c|}{$\begin{array}{l}{ }^{1} \text { Cows with a follicle } \geq 10 \mathrm{~mm} \text { in diameter at } \mathrm{PGF}_{2 \alpha} \text { and concentrations of progesterone } \leq \\
0.5 \mathrm{ng} / \mathrm{mL} 72 \mathrm{~h} \text { after } \mathrm{PGF} 2 \alpha \text { injection. } \\
{ }^{2} \mathrm{CL} \text { only; no } \mathrm{CL}+\mathrm{CIDR}=\mathrm{CL}+\mathrm{CIDR} \text { insert }(\mathrm{d} 0) \text { for } 5 \mathrm{~d} \text {; or } \mathrm{CL}+2 \mathrm{CIDR} \text { inserts }(\mathrm{d} 0) \\
\text { for } 5 \mathrm{~d} \text {. On d } 0 \mathrm{CIDR} \text { inserts were removed and all cows received } \mathrm{PGF} \mathrm{F}_{2 \alpha} \text {. } \\
{ }^{3} \text { Percentage of cows expressing activity assessed by AMS or pressure-sensitive patches. } \\
{ }^{4} \text { Percentage of cows that ovulated subsequent to detection of estrus. }\end{array}$} \\
\hline
\end{tabular}


Table 3. Characteristics of estrus (LSM \pm SEM) determined by automated activity monitoring system (AMS) or by a pressure sensitive device for qualifying cows in experiment $1^{1}$

\begin{tabular}{|c|c|c|c|}
\hline \multirow[b]{2}{*}{ Item } & \multicolumn{3}{|c|}{ Treatment $^{2}$} \\
\hline & CL only & no $C L+C I D R$ & $\mathrm{CL}+2 \mathrm{CIDR}$ \\
\hline \multicolumn{4}{|l|}{ AMS } \\
\hline Onset of estrus ${ }^{3}, \mathrm{~h}$ & $77 \pm 6$ & $67 \pm 5^{* *}$ & $78 \pm 6$ \\
\hline Duration of estrus, $\mathrm{h}$ & $12.4 \pm 1.1$ & $11.0 \pm 1.0$ & $11.9 \pm 1.1$ \\
\hline Mean counts ${ }^{4}$ & $111 \pm 12$ & $106 \pm 12$ & $100 \pm 12$ \\
\hline Peak counts & $135 \pm 19$ & $142 \pm 18$ & $133 \pm 19$ \\
\hline Mean factor ${ }^{5}$ & $3.8 \pm 0.3$ & $4.1 \pm 0.3$ & $3.9 \pm 0.3$ \\
\hline Peak factor & $4.4 \pm 0.5$ & $5.4 \pm 0.5$ & $5.9 \pm 0.5^{*}$ \\
\hline \multicolumn{4}{|l|}{ Pressure-sensitive device } \\
\hline Onset of estrus ${ }^{3}, \mathrm{~h}$ & $66 \pm 6$ & $59 \pm 5$ & $79 \pm 5$ \\
\hline Duration of estrus, $h$ & $6.5 \pm 1.1$ & $4.6 \pm 0.8$ & $6.0 \pm 0.9$ \\
\hline Standing events, no. & $7.8 \pm 1.8$ & $6.5 \pm 1.4$ & $6.1 \pm 1.6$ \\
\hline Total duration of stands, $\mathrm{s}$ & $16.9 \pm 3.7$ & $12.6 \pm 3.0$ & $12.2 \pm 3.2$ \\
\hline
\end{tabular}

Different $(P<0.05)$ from CL only.

${ }^{* *}$ Different $(P<0.01)$ from CL only.

${ }^{1}$ Cows with a follicle $\geq 10 \mathrm{~mm}$ in diameter at $\mathrm{PGF}_{2 \alpha}$ and concentrations of progesterone $\leq$ $0.5 \mathrm{ng} / \mathrm{mL} 72 \mathrm{~h}$ after $\mathrm{PGF}_{2 \alpha}$ injection.

${ }^{2} \mathrm{CL}$ only; no CL + CIDR $=\mathrm{CL}+\mathrm{CIDR}$ insert $(\mathrm{d} 0)$ for $5 \mathrm{~d}$; or CL +2 CIDR inserts (d 0) for $5 \mathrm{~d}$. On d 0 CIDR inserts were removed and all cows received $\mathrm{PGF}_{2 \alpha}$.

${ }^{3}$ From CIDR removal to onset of estrus as determined by AMS or pressure sensitive device.

${ }^{4}$ Arbitrary units quantify motion detected by AMS.

${ }^{5}$ Standard deviation increase of motion from the previous $3 \mathrm{~h}$ of activity. 
Table 4. Occurrence of estrus and ovulation in all cows fitted with an activity monitoring system (AMS) and a friction-activated patch in experiment $2^{1}$

\begin{tabular}{|c|c|c|c|}
\hline \multirow[b]{2}{*}{ Item } & \multicolumn{3}{|c|}{ Treatment $^{2}$} \\
\hline & ECP & $\mathrm{TP}$ & Control \\
\hline AMS & & $\%(\mathrm{n})$ & \\
\hline Estrus expression ${ }^{3}, \%$ & $78.7(68)$ & $67.4(68)$ & $70.2(67)$ \\
\hline Estrus and ovulation ${ }^{4}, \%$ & $94.9(53)$ & $89.5(46)$ & $96.0(47)$ \\
\hline \multicolumn{4}{|l|}{ Friction-activated patch } \\
\hline Estrus expression ${ }^{3}, \%$ & $84.4^{+}(63)$ & $67.7(64)$ & $71.4(60)$ \\
\hline Estrus and ovulation ${ }^{4}, \%$ & $100(53)$ & $90.3(43)$ & $93.4(42)$ \\
\hline
\end{tabular}

${ }^{+}$Tended $(P<0.10)$ to differ from control.

${ }^{1}$ All enrolled cows.

${ }^{2}$ Cows received an injection of $\mathrm{PGF}_{2 \alpha}$ and assigned randomly to 3 treatments: $\mathrm{ECP}=1 \mathrm{mg}$ estradiol cypionate; $\mathrm{TP}=2 \mathrm{mg}$ testosterone propionate; Control $=$ no treatment injection. Treatment was administered on $\mathrm{d} 1$ concurrent with a second injection of $\mathrm{PGF}_{2 \alpha}$. ${ }^{3}$ Percentage of cows expressing activity assessed by AMS or friction activated patch ${ }^{4}$ Percentage of cows that ovulated subsequent to detection of estrus. 
Table 5. Occurrence of estrus and ovulation in qualifying cows fitted with an activity monitoring system (AMS) and a friction-activated patch in experiment $2^{1}$

\begin{tabular}{|c|c|c|c|}
\hline \multirow[b]{2}{*}{ Item } & \multicolumn{3}{|c|}{ Treatment $^{2}$} \\
\hline & ECP & $\mathrm{TP}$ & Control \\
\hline AMS & \multicolumn{3}{|c|}{$\%(n)$} \\
\hline Estrus expression ${ }^{3}, \%$ & $80.1^{+}(64)$ & $66.7(66)$ & $68.5(64)$ \\
\hline Estrus and ovulation ${ }^{4}, \%$ & $96.3(51)$ & $90.4(44)$ & $100(43)$ \\
\hline \multicolumn{4}{|l|}{ Friction-activated patch } \\
\hline Estrus expression ${ }^{3}, \%$ & $87.1 *(60)$ & $67.0(62)$ & $70.3(58)$ \\
\hline Estrus and ovulation ${ }^{4}, \%$ & $100(52)$ & $91.3(41)$ & $100(40)$ \\
\hline
\end{tabular}

'Tended $(P<0.10)$ to differ from control.

*Different $(P<0.05)$ from control.

${ }^{1}$ Cows with a follicle $\geq 10 \mathrm{~mm}$ in diameter at $\mathrm{PGF}_{2 \alpha}$ and concentrations of progesterone $\leq 0.5$ $\mathrm{ng} / \mathrm{mL} 72 \mathrm{~h}$ after $\mathrm{PGF}_{2 \alpha}$ injection.

${ }^{2}$ Cows received an injection of $\mathrm{PGF}_{2 \alpha}$ and assigned randomly to 3 treatments: $\mathrm{ECP}=1 \mathrm{mg}$ estradiol cypionate; $\mathrm{TP}=2 \mathrm{mg}$ testosterone propionate; Control $=$ no treatment injection. Treatment was administered on $\mathrm{d} 1$ concurrent with a second injection of $\mathrm{PGF}_{2 \alpha}$. ${ }^{3}$ Percentage of cows expressing activity assessed by AMS or friction-activated patch.

${ }^{4}$ Percentage of cows that ovulated subsequent to detection of estrus. 
Table 6. Characteristics of estrus (LSM \pm SEM) determined by an activity monitoring system (AMS) for qualifying cows in experiment $2^{1}$

\begin{tabular}{lccc}
\hline & & Treatment $^{2}$ \\
Item & ECP & TP & Control \\
\hline Treatment to estrus, h & $45 \pm 3^{*}$ & $52 \pm 3^{+}$ & $60 \pm 3$ \\
CIDR removal to estrus, $\mathrm{h}$ & $56 \pm 5$ & $50 \pm 5$ & $58 \pm 5$ \\
Duration of estrus, h & $10.3 \pm 0.7$ & $9.9 \pm 0.8$ & $10.0 \pm 0.8$ \\
Mean counts $^{3}$ & $115 \pm 6^{+}$ & $105 \pm 7$ & $101 \pm 7$ \\
Peak counts & $205 \pm 1^{*}$ & $195 \pm 13$ & $171 \pm 13$ \\
Mean factor $^{4}$ & $4.3 \pm 0.2$ & $4.3 \pm 0.2$ & $4.2 \pm 0.2$ \\
Peak factor & $5.7 \pm 0.3$ & $6.5 \pm 0.3$ & $6.3 \pm 0.3$ \\
\hline
\end{tabular}

'Tended $(P<0.10)$ to differ from control.

${ }^{*}$ Different $(P<0.05)$ from control.

${ }^{1}$ Cows with a follicle $\geq 10 \mathrm{~mm}$ in diameter at $\mathrm{PGF}_{2 \alpha}$ and concentrations of progesterone $\leq 0.5 \mathrm{ng} / \mathrm{mL} 72 \mathrm{~h}$ after $\mathrm{PGF}_{2 \alpha}$ injection.

${ }^{2}$ Cows received an injection of $\mathrm{PGF}_{2 \alpha}$ and assigned randomly to 3 treatments:

$\mathrm{ECP}=1 \mathrm{mg}$ estradiol cypionate; $\mathrm{TP}=2 \mathrm{mg}$ testosterone propionate; Control $=$ no treatment injection. Treatment was administered on $\mathrm{d} 1$ concurrent with a second injection of $\mathrm{PGF}_{2 \alpha}$.

${ }^{3}$ Arbitrary units quantify motion detected by AMS.

${ }^{4}$ Standard deviation increase of motion from the previous $3 \mathrm{~h}$ of activity. 
Table 7. Percentage of qualifying cows $^{1}$ defined to be in estrus (efficiency), ovulated, or both (accuracy) detected by an activity monitoring system (AMS), pressure-sensitive devices, or friction-activated patches in experiments 1 and $2^{2}$

\begin{tabular}{lccc}
\hline Item & AMS & $\begin{array}{c}\text { Pressure-sensitive } \\
\text { devices }\end{array}$ & $\begin{array}{c}\text { Friction-activated } \\
\text { patches }\end{array}$ \\
\hline Experiment 1 & & $\%($ no. / no. & \\
Estrus expression & $67.9(89 / 131)$ & $61.8(81 / 131)$ & $\ldots$ \\
$\quad$ Ovulation & $94.4(84 / 89)$ & $96.3(78 / 81)$ & $\ldots$ \\
$\quad$ No ovulation & $5.6(5 / 89)$ & $3.7(3 / 81)$ & $\ldots$ \\
No estrus expression & $32.1(42 / 131)$ & $38.2(50 / 131)$ & $\ldots$ \\
Ovulation & $69.0(29 / 42)$ & $76.0(38 / 50)$ & $\ldots$ \\
No ovulation & $31.0(13 / 42)$ & $24.0(12 / 50)$ & $\ldots$ \\
Experiment 2 & & & \\
Estrus expression & $71.1(138 / 194)$ & $\ldots$ & $73.9(133 / 180)$ \\
Ovulation & $94.2(130 / 138)$ & $\ldots$ & $5.7(126 / 133)$ \\
No ovulation & $5.8(8 / 138)$ & $\ldots$ & $26.1(47 / 180)$ \\
No estrus expression & $28.9(56 / 194)$ & $\ldots$ & $59.6(28 / 47)$ \\
Ovulation & $60.7(34 / 56)$ & $\ldots$ & $40.4(19 / 47)$ \\
No ovulation & $39.3(22 / 56)$ & $\ldots$ & \\
\hline
\end{tabular}

${ }^{\mathrm{I}}$ Cows with a follicle $\geq 10 \mathrm{~mm}$ in diameter at $\mathrm{PGF}_{2 \alpha}$ and concentrations of progesterone $\leq 0.5$ $\mathrm{ng} / \mathrm{mL} 72 \mathrm{~h}$ after $\mathrm{PGF}_{2 \alpha}$ injection.

${ }^{2}$ Percentage of cows detected in estrus by $7 \mathrm{~d}$ after injection with $\mathrm{PGF}_{2 \alpha}$. 